3528

C2

$\begin{array}{lll}\text { क } & \text { b ? } 874\end{array}$

$$
x^{x}
$$




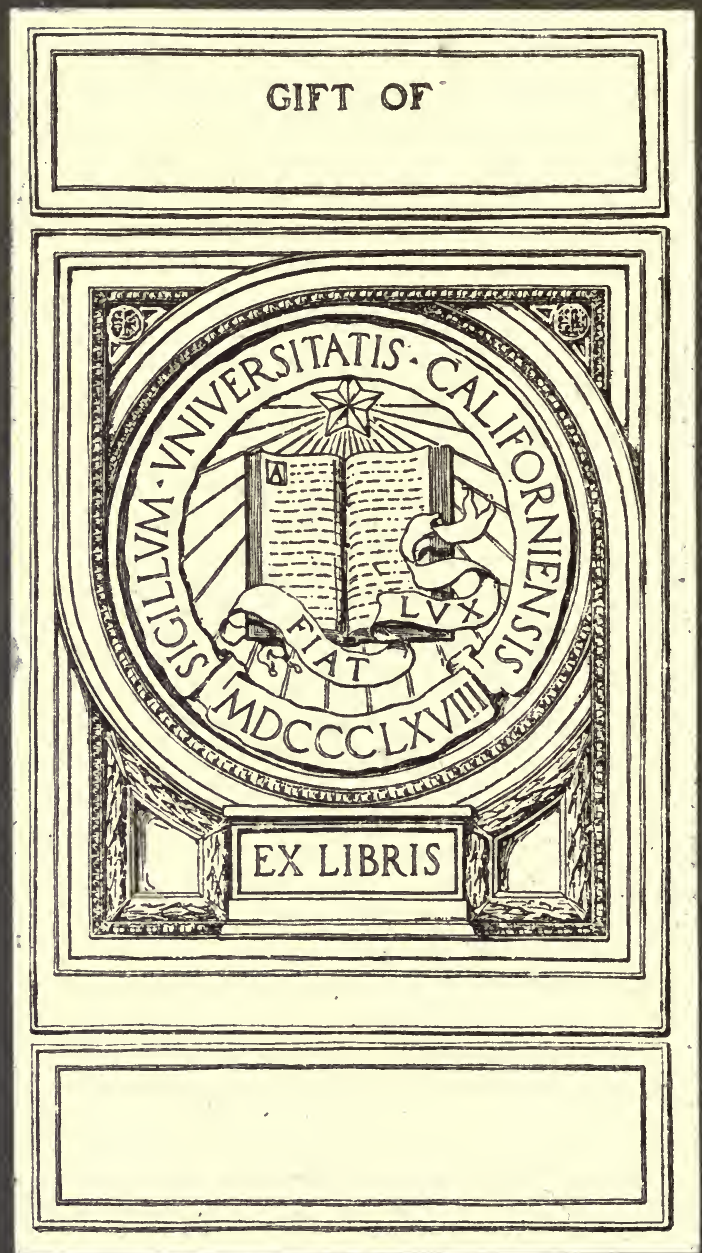




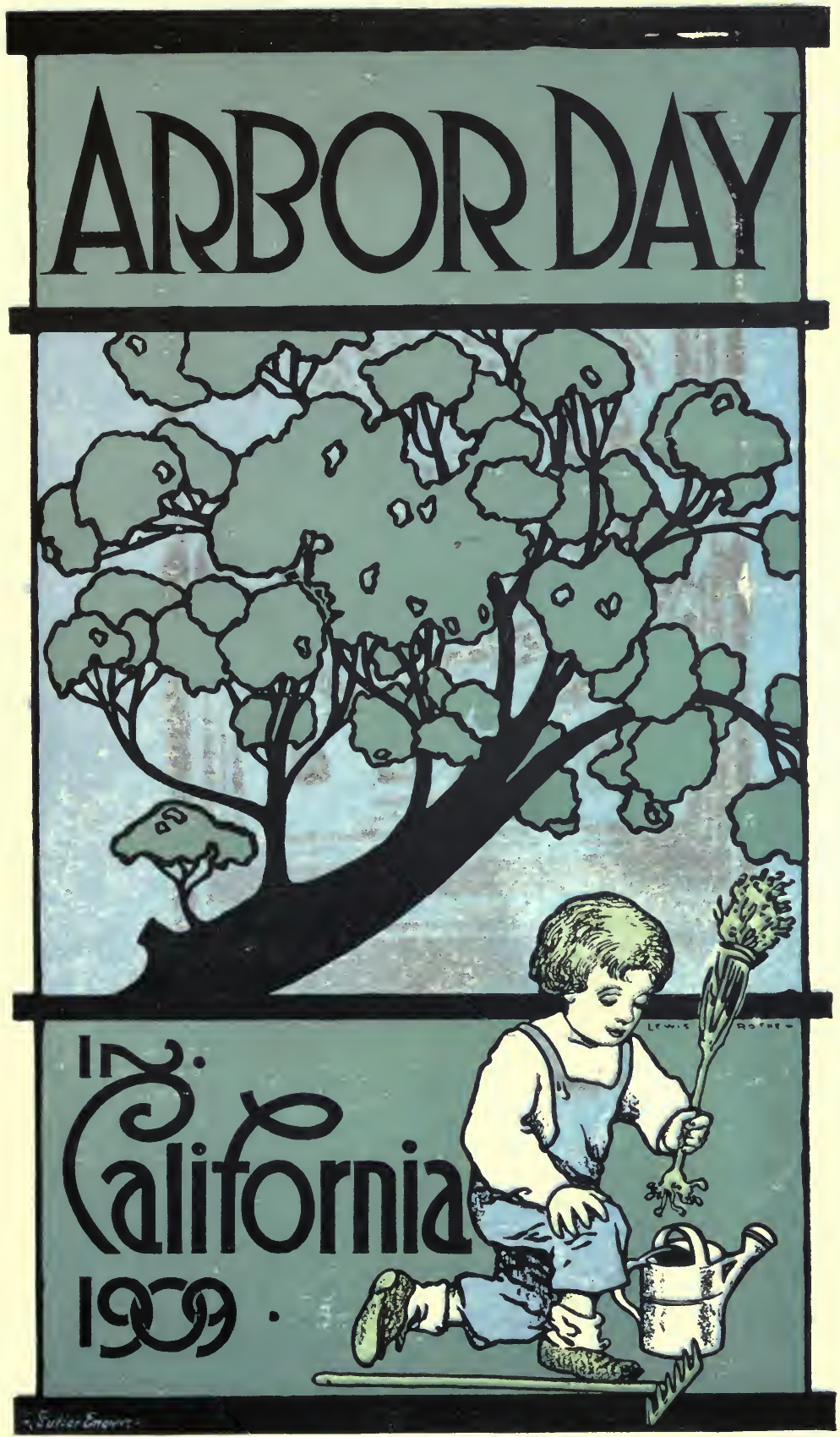





\section{STATE OF CALIFORNIA}

OFFICE SUPERINTENDENT OF PUBLIC INSTRUCTION

\section{ARBOR DAY MANUAL}

FROM THE

\section{TWENTY-THIRD BIENNIAL REPORT}

OF

\section{EDWARD HYATT}

SUPERINTENDENT OF PUBLIC INSTRUCTION 
PRINTED AT THE STATE PRINTING OFFice W. W. SHANNON, SUPERINTENDENT

$$
\begin{aligned}
& \because \because \because \quad \vdots \because \vdots \vdots \because \vdots \vdots \vdots
\end{aligned}
$$

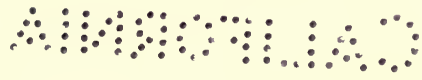




\section{TO THE SCHOOL PEOPLE OF CALIFORNIA}

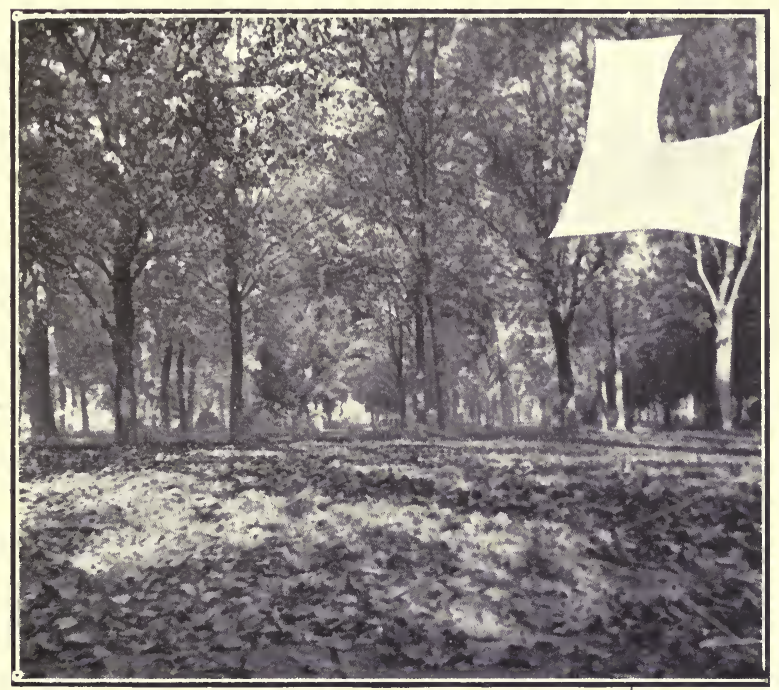

A D I ES A N D GENTLE II EN :

We have heard much of late concerning our civic duties growing out of the great movement for conservation of natural resources. The handiest tool for us to use in making practical application of the conservation idea is Arbor Day. If

we will, we may use this day to carry a patriotic spirit to the young people now in our charge; a spirit that will be the strength and safeguard of the State bye and bye.

Isn't this richly worth while?

On the theory that your answer to this question is "Yes, indeed!" we have prepared this little Arbor Day Manual, offering some suggestions and some materials to use in determining how the day may be best observed in each of your schools. Your own plan will be best for you. Do not feel constrained to follow any of these suggestions slavishly, but shape them to your ends.

\section{$* 2 *$}

At the present writing there is no date for Arbor Day fixed by the State. It is difficult to set a date for planting that is suitable throughout a State stretching nearly a thousand miles from the north to the south, and including tropic, temperate, desert, and alpine regions within its borders. There is a movement on foot to designate Luther Burbank's birthday, March 7th, as the Arbor Day for the State. Some 
county superintenderts of schools appoint an Arbor Day independently, and lead their counties magnificently to use it. An individual district, in the absence of higher action, may select an Arbor Day of its own, and ittingly celebrate it. Where there's a will there's a way.

I heartily recommend the appropriate observation of an Arbor Day to each of the school people who reads these lines. Whoever plans the ceremonies will need to take heed to the double nature of the day. First, and deepest, lies the intent to graft into our body politic a worthy idea of the TREE in its relation to our national life, with some of the fundamental patriotic duties growing out of that idea. This can be done in every school of the land, large or small, in city or country. Second, and simpler, is the intent to actually Do some concrete thing to make the earth better in future; to plant, to improve, to adorn some small part of it with loving care. Some schools, perhaps, have not opportunity for this; yet poor indeed must be the place that can not afford some vacant corner, some neighboring lot, some neglected street where the children of the school may do an unselfish piece of work on Arbor Day. There's a way when there's a will.

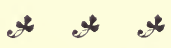

I trust this idea may appeal to you, that it may receive your attention, your energy, your thought. It can not do you any harm and it may do you good. And through you it may work great good to generations as yet unborn. I leave it with you.

Very truly yours,

EDWARD HYATT, Superintendent of Public Instruction.

\section{IN GRATEFUL ACKNOWLEDGMENT}

To those who have contributed to the Arbor Day Report we are deeply indebted. Thoughts and ideas have been freely used from the Arbor and Bird Day Manuals published by educators in New York, Ohio, Wisconsin, Oregon, Alabama, Colorado, West Virginia, and other states. We have used this information for the benefit of the people of California, believing, with a neighboring superintendent, that "whatever these publications contain relating to Arbor Day ought to be scattered broadcast and thus become the common knowledge of all, to be used by all, to arouse an active interest in tree planting among the people of our state."

To Success Magazine for material; to the Neuner Company, Sierra Madre Chamber of Commerce, and others for the loan of engravings; to Andrew Hill for his drawings; to Miss Calthea C. Vivian, Prof. H. M. Hall, Prof. A. J. Cook, and all others who have had their part and rendered valuable assistance in producing the report, we extend grateful thanks. 


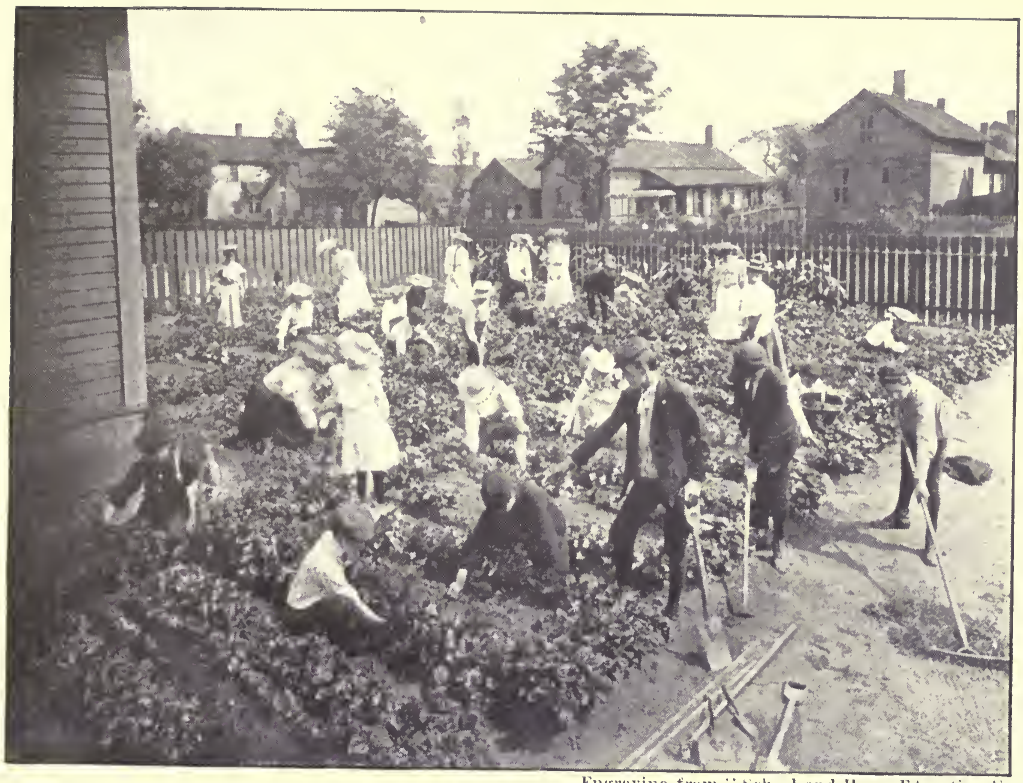

Pupils Weeding the school Garden.

Limitations of space make it necessary, through intensive culture and succession of crops, to impress upon the children the yielding capacity of a small plot of ground, thus encouraging them to utilize and develop to their highest possibility the waste space in their own home grounds.

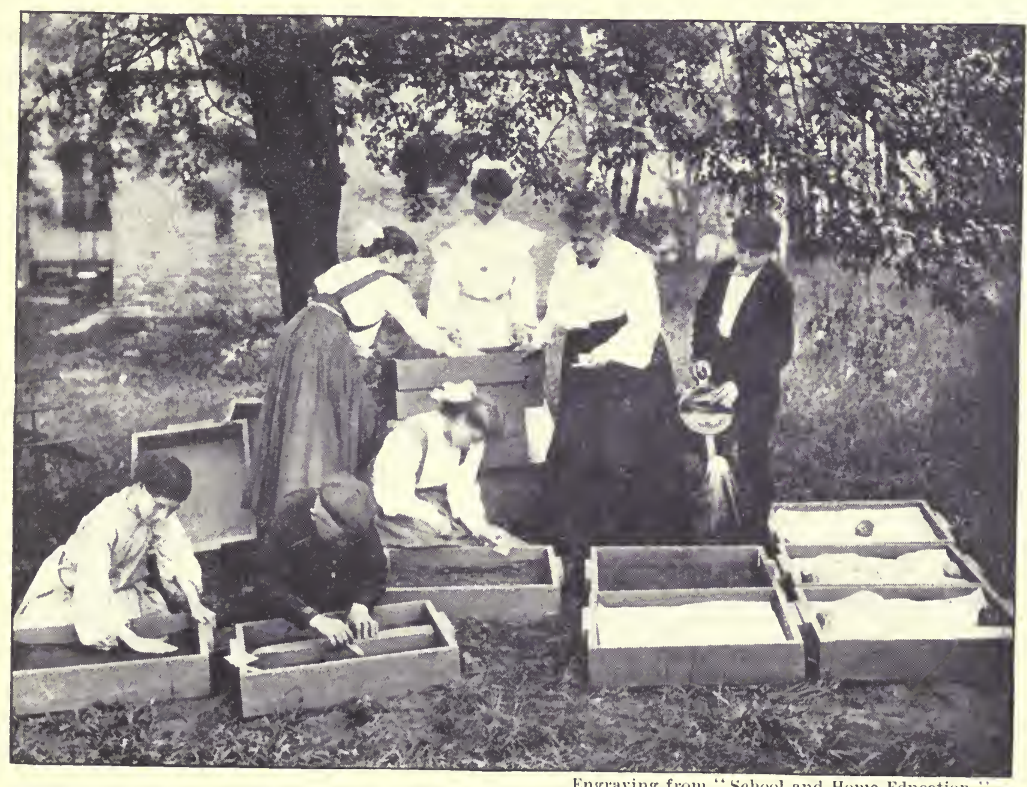

Transplanting from Hot Beds to Cold Frames.

After receiving training at a school garden, the children take great pride in laying out gardens of their own, much to the delight of interested parents. These gardens at home are, as a rule, well planned and planted, things of beauty and utility, yielding pleasure and profit to the household, demonstrating that the object for which school gardens have been established is being realized. 


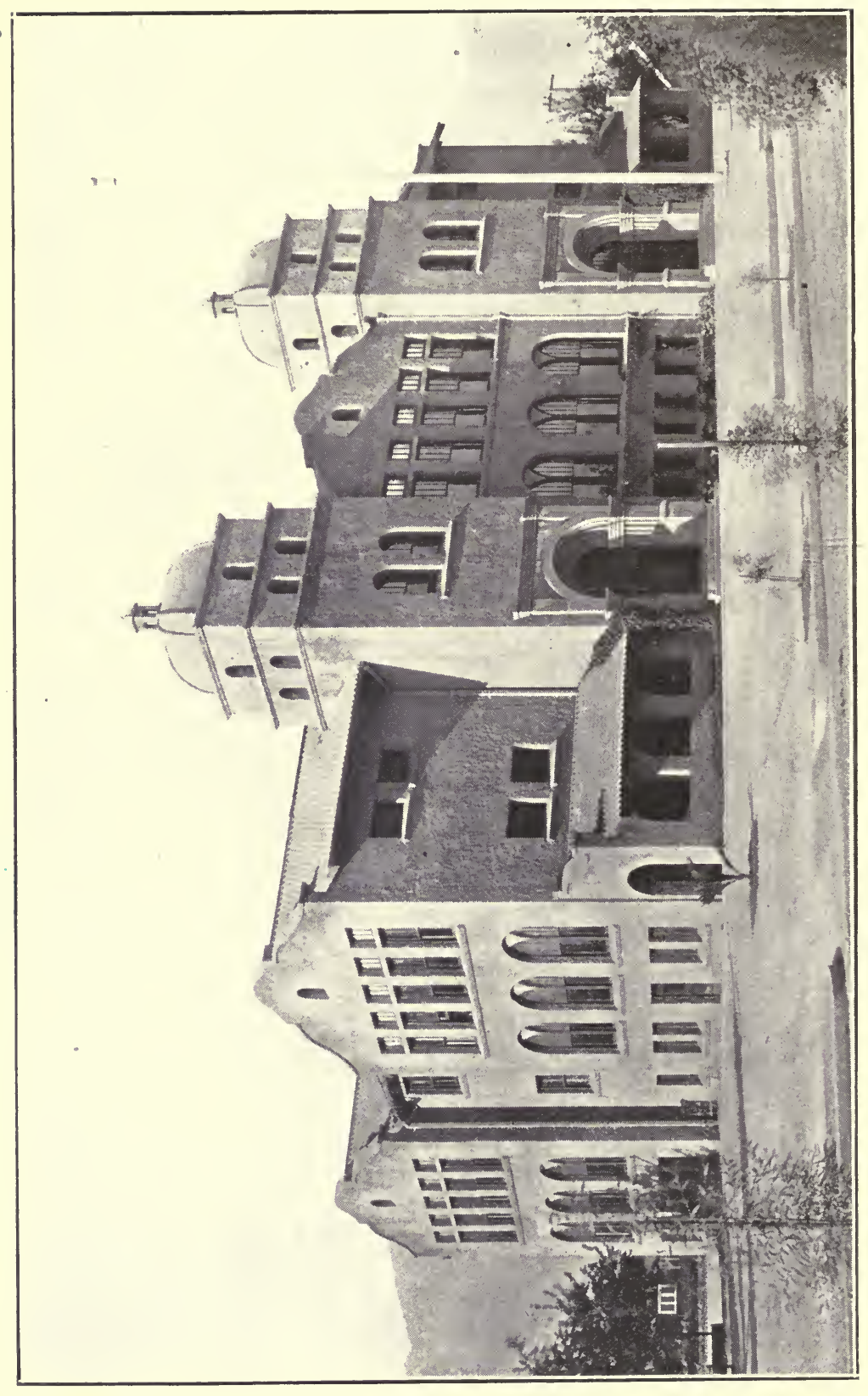

$\stackrel{Ð 2}{ \pm 2}$

ㅁ

范

는

$\stackrel{\Xi}{5}$

릴

$\stackrel{0}{3}$

雪

$\cong$

Dै

递龸

들

o

:

ธี

幽

政

궁

z

되늘

<

क

a

나요

일

范

of

'

을

政

य일

制

프

20

है



5

로

政

0

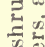

可

过

证

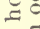

4.9

물

a

है

施至

政 

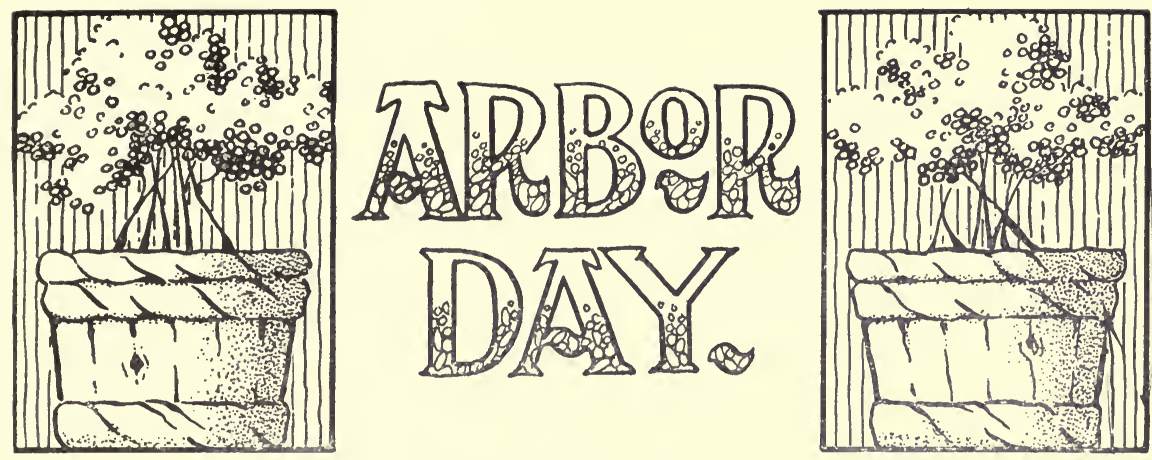

Compiled Under the Direction of

THE SUPERINTENDENT OF PUBIIC INSTRUCTION.

By LaWrence E. Chenoweth.

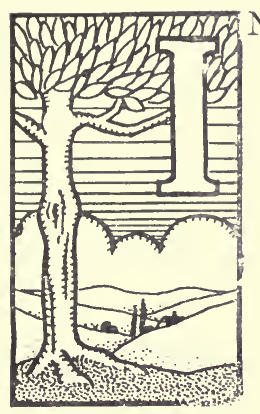

THE following pages you will find set forth ideas culled from various articles that have come to hand from time to time welded together with personal ideas and experiences, and combined into, we hope, an harmonious whole, which may be of assistance in promoring what is bound to prove of vital importance to the children of this broad land-Arbor Day.

Arbor Day provides the occasion for speaking about a great idea and for doing some things about it in all the schools. It is easy enough both in the cities and the country for the teacher to tell the children what Arbor Day signifies, and to hear what the children think about it. School exercises, with readings and recitations, do much to give meaning to the day. It is harder to DO things than to talk about them. Yet it is not difficult to clear up school grounds and plant new trees. If the children can be waked up they will find that their interest in trees and flowers and animals will grow larger and larger as they grow larger and larger themselves. They will think of things that never occurred to them before, things that will make them better citizens and more successful men and women. In every school in the state there should be set apart a day to be used to create a new love of nature in the teacher and the children, and to do something which for a long time will express that new interest in the subject.

A barren schoolroom, a barren school yard can produce naught save a barren-hearted pupil, insensible to that refining influence so neces- 
sary an accompaniment to education. Let us, then, have beautiful school interiors and sensible school exteriors throughout the State, to the end that its embryo citizens may feel for several hours at least, each day, that subtle, essential influence of social culture which walks hand in hand with educational advancement. The celebration of Arbor Day is a step in this direction. Let us make wise use of it.

\section{PLANNING THE WORK}

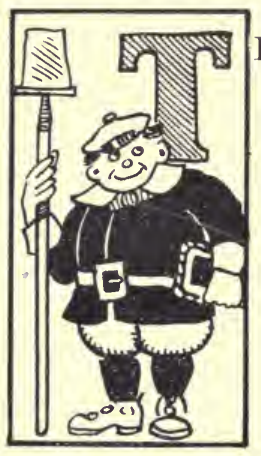

HE PLANTING of school grounds should be planned and executed with the greatest care, for the work of the school whether it be indoors or out is educational and has its influence upon the present as well as the prospective guardians of the State. The planting material should be carefully chosen and the disposition of the trees and shrubs upon the grounds made to conform to the extent, character, and uses of the grounds. The three elements to be secured in the plantings should be,

Use.

Protection.

Beauty.

While many of our schoolhouses are ideally located, there are very many of which stand in barren and bleak places, and which make little or no pretense to beauty of surroundings. The location of the schoolhouse can not be changed, but the surroundings may be made beautiful. Trees and shrubs, vines and flowers may be induced to grow in any part of California. Desolate playgrounds may be made shady and delightful. Ugly fences and buildings may assume lovely and graceful shapes. Corners and odd places may be made spots of beautiful color.

A first essential in beautiful school grounds is tidiness. No loose sticks, stones, pieces of paper, or other offending material should be

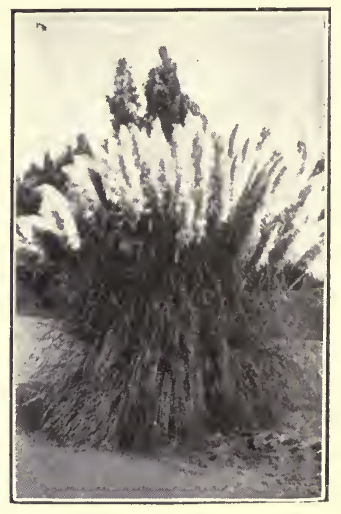
seen lying about. It is never impossible to keep the grounds neat. It is impossible to make them beautiful if they are not kept neat. 


\section{AWAKENING AN INTEREST}

Before anything is done toward improving the grounds, it is best to try to awaken an interest in the pupils and in the older members of the community. You will work against odds if you undertake to work alone. It may require tact and patience, but the friends of the school must be brought to a desire to improve the school grounds, to take pride in them, and to wish to help in making them beautiful. Do not despair if this is difficult of attainment. It has always been so.

We would begin something like this, assuming that the yard is fenced. If it is not, then the teacher will have a little harder task. Let the teacher decide to celebrate an Arbor Day by planting some trees or

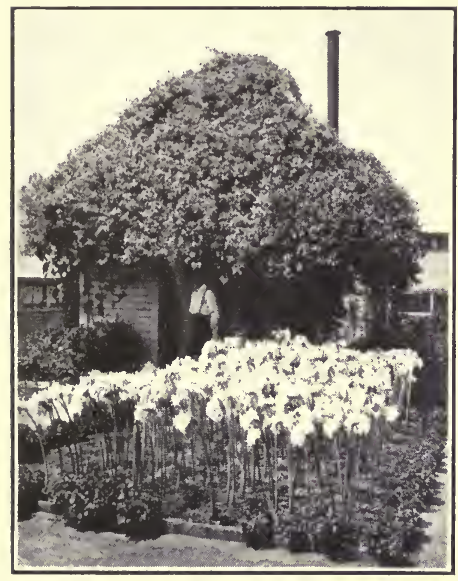
shrubs and having any other exercises he likes. The first thing he will do, of course, is to talk to the trustees about it. They will say that they are very busy; that they have tried planting trees before; and that they do not believe it will pay. Let their excuses go in at one ear and out at the other. Keep after them, judiciously of course, but don't take "No" for an answer. They are patient men, at least all the trustees we know are. Get their wives and other women of the neighborhood interested. Find out where trees which will grow in that particular section can be obtained, and plan some way to get some. Plan for a basket lunch with the children at noon. Get some of the men to promise to come and dig holes for the trees. Get some one to bring three or four barrels of water, if there is not sufficient water at the schoolhouse to give each hole a half barrel, and each tree a half barrel after it is planted.

A plan of the grounds should always be made before any work is done, and on this plan should be indicated the exact spots for planting trees, shrubs, vines, and flowers. The first thing to locate, however, is sufficient playground for the children. The latter must always have room to run and play, and must never feel restricted by the too near presence of flowers and shrubs. But even after large clear play spaces have been set aside you will find ample room for ornamentation. Then plan with care and for years to come. Trees and shrubs are so slow of growth that no mistakes in original planting can

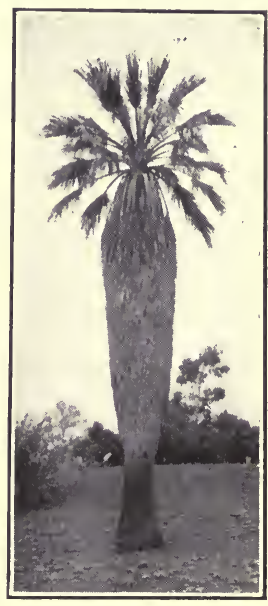
be afforded. 
Let me urge on you, in making your plan, not to waste your energies in placing great quantities of varieties of plants and flowers in the space given, or in stripping away all the old landmarks and reducing your grounds to formal gardens of walks and beds and borders, but to take things as you find them, to study them closely and in detail, and in their relation to the whole, that you may know best what use to make of them; and above all to get such a conception of the possibilities of that bit of landscape which you have set about to beautify, that you will arrange for the planting of no tree or shrub or vine without first being able to see just what its relation to your whole scheme will be.

\section{THE PLAN}

The first essential for the work of beautifying the grounds will be a plan. The beginning of this plan may be a rough sketch of the area on which the school building stands, with directions and distances marked upon it. Next, locate the permanent objects, such as trees and buildings. Determine next the main lines of travel leading to the

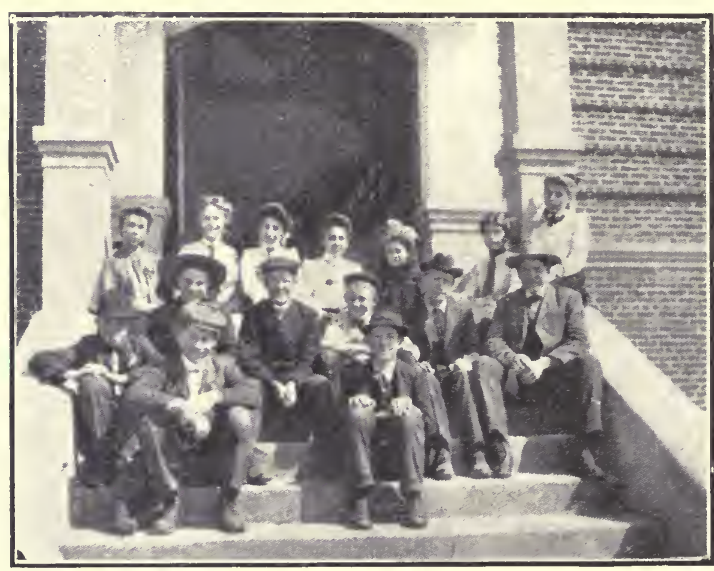

"Pleasant School Surroundings Make Happy Hearts and Smiling Faces." schoolhouse and use these as a basis for the permanent walks, unless there is some good reason for changing the main paths. The walks and drives should be straight, if distances are less than 100) feet, and gently curved if longer, so as to admit of the use of trees and shrubs along the border. The outlook from each door and window should be carefully inspected before determining which objects in the landscape should be retained in view and which hidden or concealed by the use of trees and shrubs.

Trees and shrubs should be confined chiefly to the borders of the place, and in rural schools the trees should be so located as to give protection from storms in winter and from the sun in summer, and at the same time to produce a pleasing effect. Shrubs may be employed to an advantage in screening unsightly objects. The plans of the grounds will serve both as an exercise in geography and arithmetic, and if the pupils are encouraged to make such designs that their interest in the work will be assured and a practical application of the principles taught in the schoolroom will be a result of no little value. 


\section{WHAT TO PLANT}

Lawns are the foundation of all decorative planting. A good, wellkept lawn contributes more to the beauty of grounds than any other single factor. They require constant attention, a sure water supply and are therefore possibly only practicable in city school yards where a gardener is employed the year round.

\section{SHRUBS}

C HRUBS should never be planted singly in

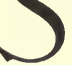
the school yard, but should be grouped in masses in fence corners and elsewhere. The location of the shrubbery should be very definitely indicated on the school ground plan. Large groups of shrubs may be used as screens for outbuildings. Use the taller varieties as a background and plant the lower in front. If it is desired to plant shrubbery along a fence line, do not plant with geometric exactness, but let the outline waver, showing high dense masses in some places and perhaps only single low bushes in others.

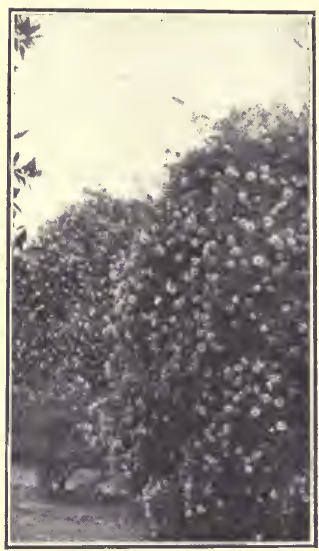

\section{VARIETIES OF SHRUBS}

The Lilac is one of the best shrubs for school grounds. Its deep green leaves make a good screen during most of the year, and the masses of beautiful, delicately-tinted and perfumed blossoms come during the school term. It is especially free from insect attack.

Euonymus Japonicus depends upon its strongly-colored yellow and green leaves for its beauty. Grows equally well in the north or south and is a hardy.shrub.

Syringea or Mock Orange grows well, and produces excellent foliage and pretty white blossoms.

Pomegranate when planted thickly, is good in fence corners and along roadways. Its brilliant scarlet flower and large, peculiar fruit, filled with juicy morsels, make it a valuable addition to school plantations.

Bridal Wreath is showy when in bloom, and is a good "filler."

Oleander grows well, produces a strong foliage, and bears an abundance of flowers. It is said to be poisonous for stock.

Portugal Laurei is splendid, forming a solid pyramidal mass of green. Cherry Laurel makes a larger tree, equally as good, not pyramidal. Both have large, glossy evergreen leaves. The Cherry Laurel has semiedible fruits. Neither of these is a true laurel. Our Native Laurel, or Bay Tree, is splendid for some places. 


\section{VINES}

V

INES are wonderful beautifiers and may be used to cover almost any unsightly spot on the sehool grounds. They look well climbing over porches and between windows, overold stumps and along fences. It is probably best not to plant vines so that they will come directly in contact with the outside of the school building, though in some cases they may preserve rather than injure it. Professor Clark gives the following device for protecting the building: "If it is deemed advisable to have the vines on the school

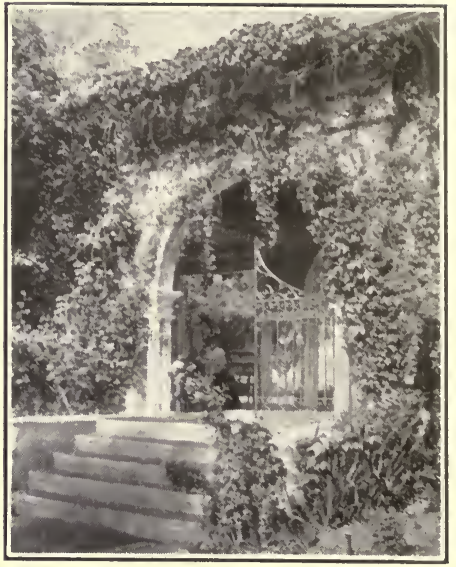
building, netted wire fencing may be attached to the cornice. First drive staples into the cornice where it is desired to fasten the support for the vines. Then bend the free ends of the wire netting and hook them directly into the staples. The lower end of the fencing may then be fastened securely to the stakes driven into the ground directly below the cornice. This support can be taken down without injury to the vines whenever it is desirable to paint the schoolhouse."

\section{VARIETIES OF VINES}

MonNAGG-Gok grows vigorously and is an active climber. Its large leaves and great bright-colored flowers will hide unsightly outbuildings and efface rough lines and poorly made fences. The variety locally known as "moon vine" is very desirable; it is vigorous with no irrigation,

Vikgria (Jkerere is a royal vine clinging tenaciously to that which supports it and is an excellent vine for all decorative purposes. Very attractive on brick walls.

Irr, though somewhat slow growing, can be used to a great advantage as a screen for woodsheds, outbuildings, and the like, and when grown, its prunings afford the teacher a constant supply for interior decorations.

HoNer Suckite winds and wreaths itself about its support prettily and brings bright colored leares and delicate clusters of slender white blossoms whose sweet perfume attracts butterty and bee.

JAsmine grows well in the southern section: its leares are dainty and the perfume from its tiny blossoms is exquisite.

TrumPET F LowEk grows on a sprangly, shade affording vine; the flowers are trumpet-shaped, and of a dark red hue. 
Roses of climbing varieties are excellent, if pruned and cared for.

The Banksia are very desirable, as they are beautiful and thornless. They are excellent to plant close by hydrants.

The Tecomas are very fine as vines. These and the Bignonias are very beautiful, and as they are rapid growers, they are very desirable in the southern part of the State. They are in blowm for a long time. The different colored flowers give chance for attractive variety.

Plumbago is one of our most attractive and most desirable vines in the southern counties. The great lavender colored bloom of the large flowered solanum makes it one of our most choice vines. It is tender of frost.

\section{FLOWERS}

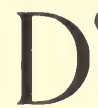

O NOT too greatly indulge your taste for flowers. Flowers recuire more attention than hardy shrubs and vines, and when school is closed for the long vacation they are apt to suffer. However, if arrangement can be made to give them proper care, a few perennials, and even some annuals may be planted if they are confined to borders and outof-the-way places. It should also be remembered that flower beds are unsightly mounds during a great portion of the year. A few hollyhocks near one of the buildings will help to decorate, while a bed of variegated nasturtiums will give a flaming patch of color and, like the cosmos, will afford material for drawing or for color lessons. There are several hardy varieties of geraniums which grow well and without a great deal of attention.

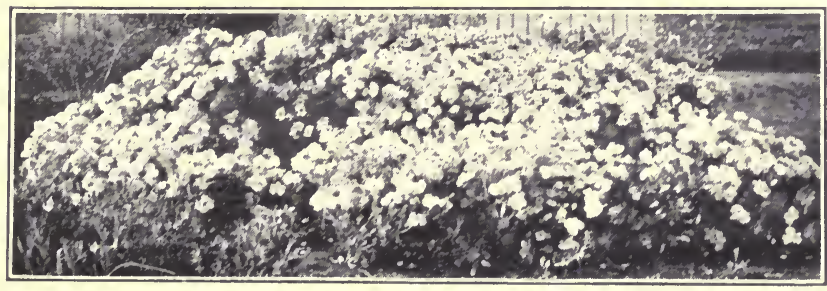

Frequent enrichment of the soil is necessary to the proper growth of flowers. Aside from those named, there are few flowers suitable for school yard planting, especially in the rural districts.

\section{$* 2 . *$}

There never was a mystery

But 'tis figured in the flowers;

Was never secret history

But birds tell it in the bowers. 


\section{VINES}

$\mathrm{V}$

INES are wonderful beautifiers and may be used to cover almost any unsightly spot on the school grounds. 'They look well climbing over porches and between windows, over old stumps and along fences. It is probaluly best not to plant vines so that they will come directly in contact with the outside of the school building, though in some cases they may preserve rather than injure it. Professor Clark gives the following device for protecting the building: "If it is deemed advisable to have the vines on the school

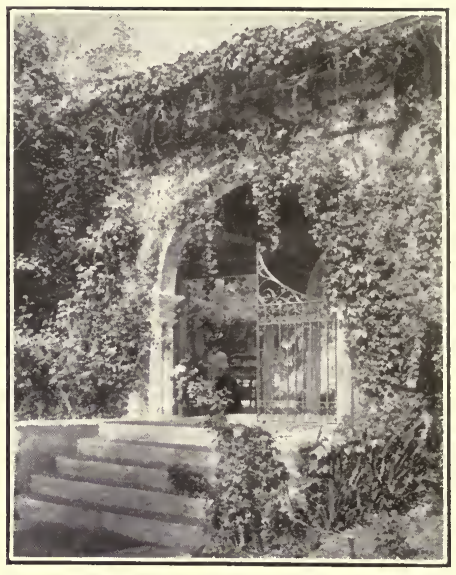
building, netted wire fencing may be attached to the cornice. First drive staples into the cornice where it is desired to fasten the support for the vines. Then bend the free ends of the wire netting and hook them directly into the staples. The lower end of the fencing may then be fastened securely to the stakes driven into the ground directly below the cornice. This support can be taken down without injury to the vines whenever it is desirable to paint the schoolhouse."

\section{VARIETIES OF VINES}

MORNING-GLORY grows vigorously and is an active climber. Its large leaves and great bright-colored flowers will hide unsightly outbuildings and efface rough lines and poorly made fences. The variety locally known as "moon vine" is very desirable; it is vigorous with no irrigation.

ViRgINIA (YREEPER is a royal vine clinging tenaciously to that which supports it and is an excellent vine for all decorative purposes. Very attractive on brick walls.

Ivy, though somewhat slow growing, can be used to a great advantage as a screen for woodsheds, outbuildings, and the like, and when grown, its prunings afford the teacher a constant supply for interior decorations.

HoNey Suckle winds and wreaths itself about its support prettily and brings bright colored leaves and delicate clusters of slender white blossoms whose sweet perfume attracts butterfly and bee.

JASMINE grows well in the southern section: its leaves are dainty and the perfume from its tiny blossoms is exquisite.

Trumpet Flower grows on a sprangly, shade affording vine; the flowers are trumpet-shaped, and of a dark red hue. 
RosEs of climbing varieties are excellent, if pruned and cared for.

The Banksia are very desirable, as they are beautiful and thornless. They are excellent to plant close by hydrants.

The Tecomas are very fine as vines. These and the Bignonias are very beautiful, and as they are rapid growers, they are very desirable in the southern part of the State. They are in bloom for a long time. The different colored flowers give chance for attractive variety.

Plumbago is one of our most attractive and most desirable vines in the southern counties. The great lavender colored bloom of the large flowered solanum makes it one of our most choice vines. It is tender of frost.

\section{FLOWERS}

D

O NOT too greatly indulge your taste for flowers. Flowers require more attention than hardy shrubs and vines, and when school is closed for the long vacation they are apt to suffer. However, if arrangement can be made to give them proper care, a few perennials, and even some annuals may be planted if they are confined to borders and outof-the-way places: It should also be remembered that flower beds are unsightly mounds during a great portion of the year. A few hollyhocks near one of the buildings will help to decorate, while a bed of variegated nasturtiums will give a flaming patch of color and, like the cosmos, will afford material for drawing or for color lessons. There are several hardy varieties of geraniums which grow well and without a great deal of attention.

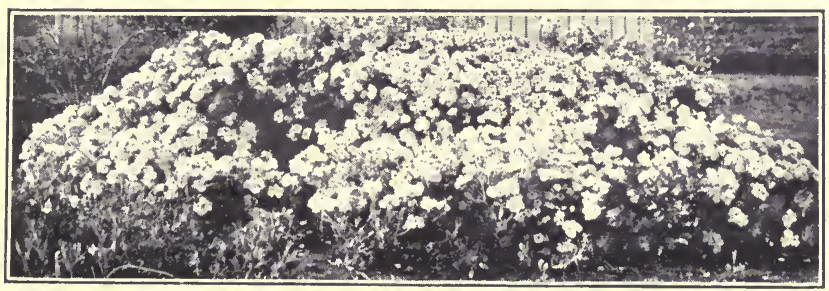

Frequent enrichment of the soil is necessary to the proper growth of flowers. Aside from those named, there are few flowers suitable for school yard planting, especially in the rural districts.

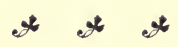

There never was a mystery

But 'tis figured in the flowers;

Was never secret history

But birds tell it in the bowers. 


\section{SUGGESTIONS FOR WINDOW BOXES}

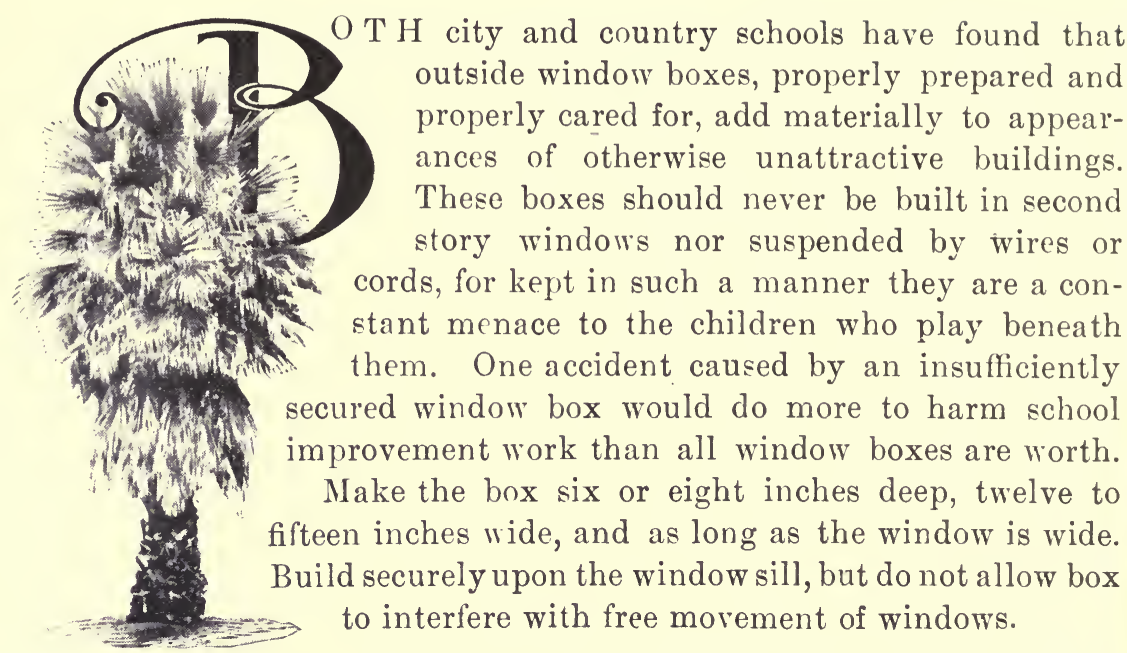

Fill the boxes with fine, rich soil, and fasten firmly to the sunniest window. Place similar boxes on the porch or fence. Plant morning-glories on the side nearest the house and train up on strings. Plant climbing nasturtiums near the outside to hang down over the box.

Plant marigolds, asters or verbenas in middle of box. Plants should stand four or five inches apart.

Boxes need water every day.

In watering care should be taken not to overflow the box so that the adjacent school wall will become soil-stained and defaced. Plant the flowers that will grow best in cramped quarters and are best suited for decorative and nature study purposes.

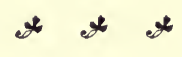

The best and highest thing a man may do in a day is to sow a seed, whether it be in the shape of a word, an act, or an acorn. 


\section{SAVE THE BIRDS!}

BY HENRIE'TTA F. GROUT.

W

HEN the equilibrium is destroyed between plant and insect life by the destruction of insect eating and seed eating birds, man suffers. One of the objects of the Audubon Society is to create a sentiment against the slaughter and use of birds for decoration, and now that the furor is at its height, the thousands of members throughout the country should at least do some active work in creating a public sentiment against this cruel fad. It is to be confessed with shame that woman's love of ornament has, in the last year, led to the destruction of thousands of humming birds, bobolinks and red wing blackbirds. Texas alone furnished 10,000 white egrets and one village in Long Island sent 70,000 bird skins to the New York market. The small state of Delaware furnished 20,000 in two months. The total slaughter the past year reached $500,000,000$ birds in our own country, whose plumage was used to decorate women's hats.

Thoughtlessness and ignorance can no longer be used as excuses for this barbarous fashion. So many appeals have been made to the head and heart of women throughout our country, and many noble women have pledged themselves to wear no bird plumage but ostrich feathers. Let us women continue the crusade. Let the women say the word and this useless sacrifice of bird life will cease and farmers will not need to spend $\$ 400,000,000$ annually in destroying insects, the birds will eat their natural food, insects, grubs and weed seeds, and our eyes and ears will be delighted with the beautiful forms and sweet songs of innumerable birds. 


\section{TREES}

YU may have some fine trees growing on the school grounds, but if you have not, a few strong specimens should be set out. Some may also be planted outside the grounds, along the road. If the trees selected embrace both timber, fruits, and ornamentals, the greatest variety will be afforded both for skill in planting and for study. The timber trees should be representative of the region and include both

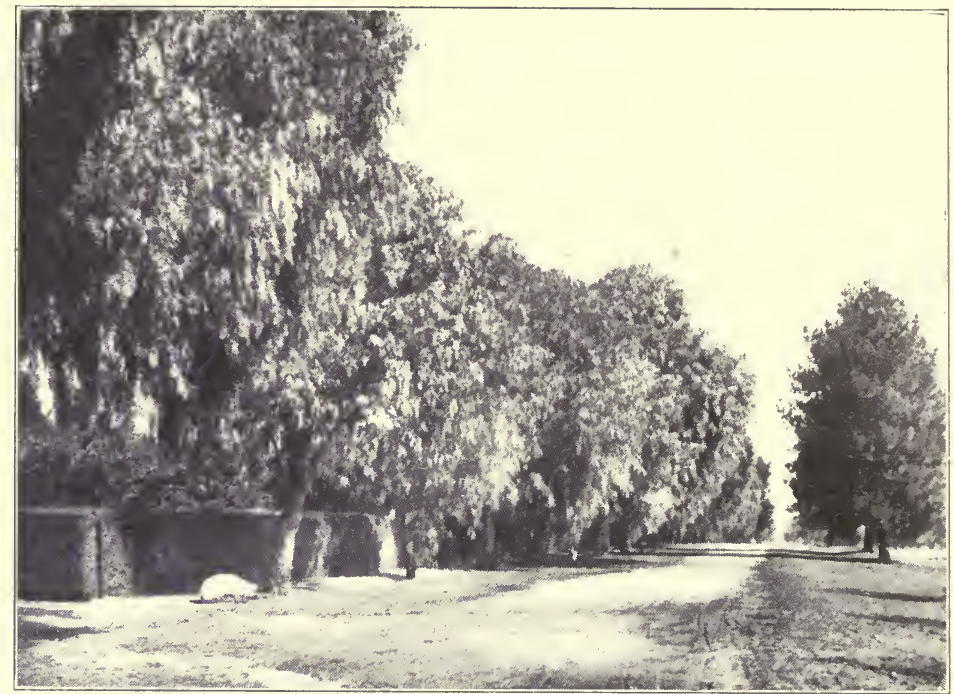

deciduous and evergreen species. The preponderance of the species need not be based on the natural forest of the region; on the contrary it will, in a majority of cases, be found most desirable to have a predominance of deciduous trees in the school ground plantings.

Trees are protective in proportion to their power to deflect or break the force of the wind and the part they play in screening or shutting out undesirable and obtrusive objects in the landscape. They are beautiful as individuals because of their foliage, flowers, or habit of growth, and collectively in proportion to the harmony existing in their ever-changing colors or their manner of growth. In fact trees, like individuals, possess marked family characteristics; in the tree these peculiarities produce its expression. The expression of some trees is somber and sad, of some, bright and happy, and of others dignified and strong. The aspect of a place, as well as its effect, upon those who frequent it is largely determined by the expression given it by the plants surrounding it. Trees, without our knowing it, exert a decided influence upon us. If we are in harmony with them they rest and inspire us; if downcast, and the expression of the trees about us is somber, we get the blues and become discouraged. The expression of 
the trees used about the home or the school should be elevating and inspiring rather than somber and depressing.

The United States Department of Agriculture has the following to say about trees to plant in school grounds:

The first rule to lay down is to plant only the kinds that are known to be hardy. A school-ground plantation is no place for experiment. Naturally the trees will have to endure greater hardships than those of private plantation; they will be likely to have less cultivation and be subject to more abuse. No matter how strict the rules, the soil about them will be more or less trampled, and twigs will sometimes be broken from their tops. Any tree that can not endure moderate abuse of this kind should not be given a place on the school ground.

On account of difference in soil, a tree that thrives in one place in a locality may not thrive in another place. Sandy soils and clay soils are often found near together, and trees that grow thriftily in sandy soil may have a hard struggle to exist when planted in clay. For this reason both the soil and the subsoil of the school ground should be carefully examined, and a list should be made of trees in the neighborhood that are thriving on soils of the same character, and no other species should be used. Much better success may be expected with a soil and subsoil of a porous character than with one that is tenacious and impenetrable. Yet a careful study will show numerous species adapted to each kind of soil.

The school ground being permanent and the need of trees continuous, for the most part long-lived trees should be used. But where the present need of trees is great, there is another side to the question.

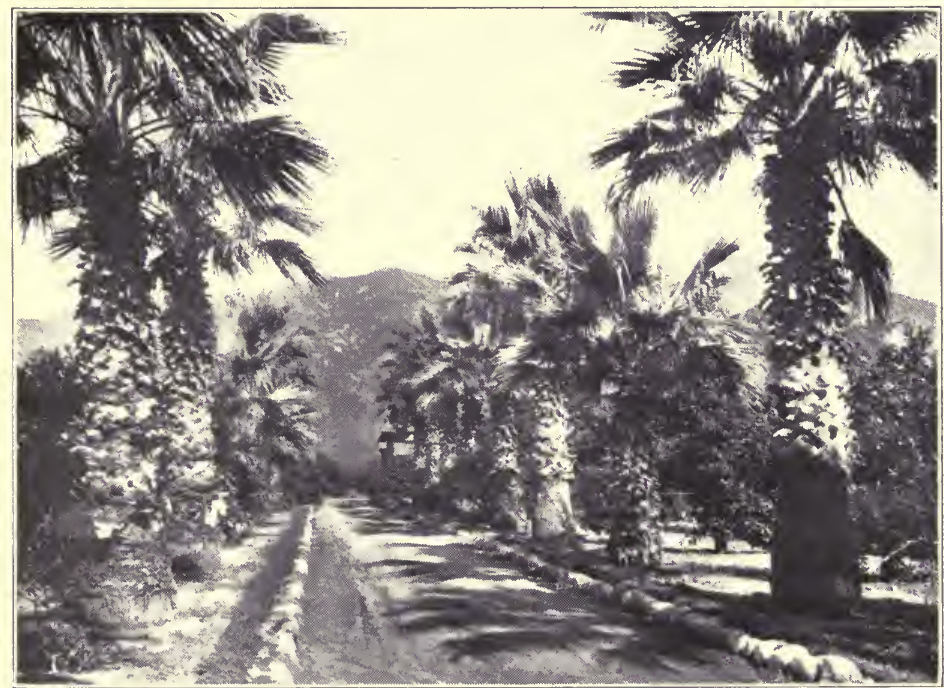

short-lived tree grows quickly, coming into early usefulness, and serves its purpose for from twenty-five to fifty years. A long-lived tree usually 
grows more slowly, but serves its purpose for a century or more. In many cases it is advisable to use the two kinds in such a way that the long-lived trees will become useful about the time the short-lived trees reach maturity. The latter then can be removed, leaving the ground to the long-lived trees.

\section{TREE PLANTING}

$T$ REES for school grounds and yards, along roadsides and streets, must be such as are least liable to suffer from injuries; they should be compact and symmetrical in shape, free from objectionable habits, such

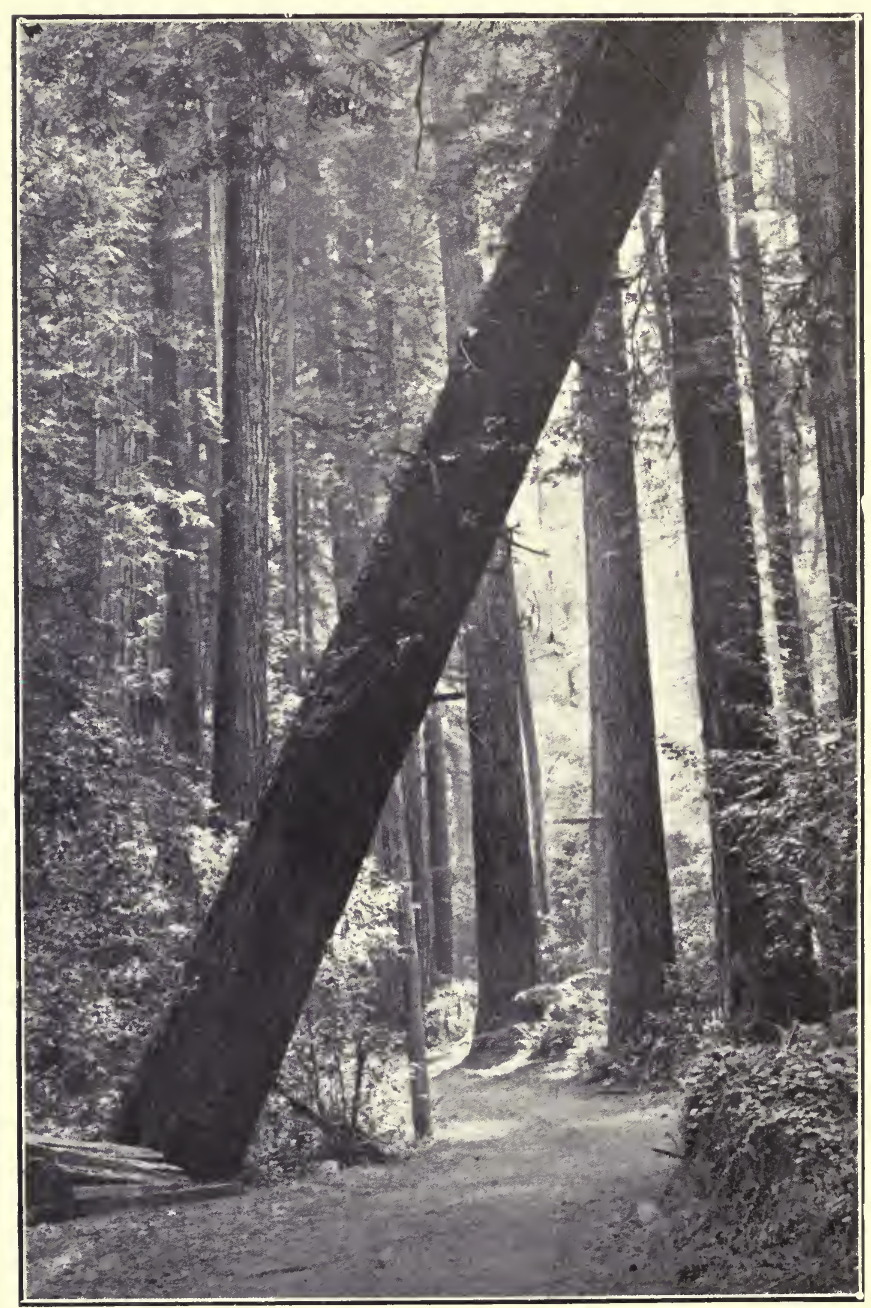

The Groves Were God's First Temples. as bad odors, root-sprouting, frequent dropping of parts, and from insect pests, and, if planted for shade, should have a broad crown and a dense foliage, budding early in the spring and retaining leaves long into the fall.

Trees native to the region in which the planting is done usually have more promise of success and are generally less costly than exotics. Trees from well managed nurseries are preferable to those grown in the forest, because 
their root-system is better prepared for transplanting. Rapidly growing trees, although giving shade soonest, are mostly shortlived and become the soonest unsightly. Trees from the forest have a wide-spreading root-system, which is difficult to take up and transplant. Those which have grown in the shade of the forest, as a rule, do not start easily in the open sunlight; those from the cool north sicles are apt to sicken when placed in hot exposures, and vice versa. A healthy tree transferred from poor soil into better conditions will show itself grateful by vigorous development. If forest trees must be used, it is better to select those growing on the edges and thus most isolated, because they have already learned to protect themselves by growing heavier bark. If trees growing in thick woods are taken up they are almost sure to die, no matter how much care is given them; because they are accustomed to protection from surrounding trees and brush.

Do not try to transplant very large trees. Trees of any size can be successfully transplanted; but in proportion to the size grows the difficulty, the amount of work, and the care necessary. As a rule the largest size should not exceed two to three inches in diameter at the base and ten to fifteen feet in height. Those

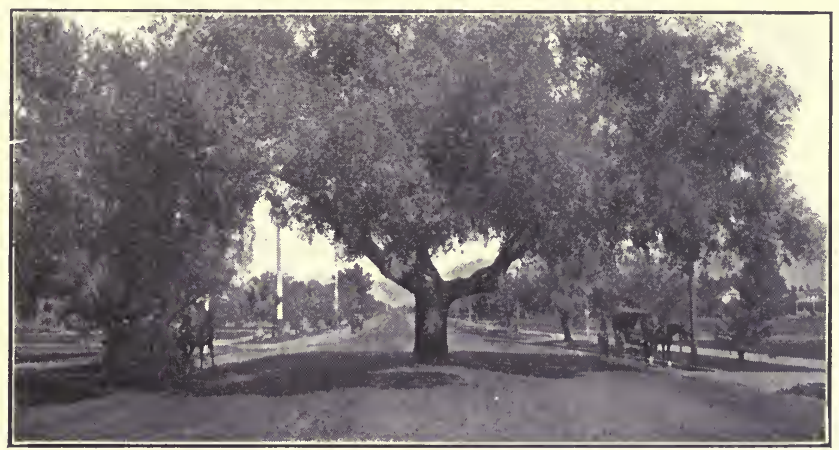
one half that size will probably make better growth, because less of their root-system will be curtailed in taking them up for transplanting. A tree suitable for transplanting should have $(a)$ an abundance of fibrous roots $(b)$ in a normal form, and $(c)$ a well proportioned development of shaft and crown.

\section{THE WORK OF TRANSPLANTING}

Transplanting is an artificial process, requiring both knowledge and care. If there is a skilled tree-planter in the neighborhood, interest him in Arbor Day; take his advice about the better trees to plant first and their location, and get hin to see that roots and branches are properly pruned, that the holes are of the proper size and depth, that the soil is filled in around the roots as it should be, and that the tree is properly protected. If he will let the older pupils assist him in doing the actual work, and afterward talk to them in a simple, direct way 
about the care of the trees, so much the better. Be sure to give him the opportunity.

The time for transplanting trees varies with the locality and the season. Trees should be moved before they have budded and blossomed, for after the leaves have opened they can not obtain sufficient nourishment from the newly planted roots, and after sapping the life from the tree, wither and die.

In considering how the transplanting is to be done we must remember that a tree is a thing of life, that it can not be removed from its place of growth and set in another place without interfering for a time with the regular operation of its vital forces. For this reason the transplanting should be done at a season when the vital forces are least active, and care should be taken to avoid as much as possible all injury to the roots of the tree, both in taking it up and in resetting it. The time between the two operations should be as short as possible, and during the interval the roots should be entirely protected from both sun and wind by covering them with damp moss or dipping them in a thin mud made by mixing rich soil and water, and then wrapping them in a coarse damp cloth or canvas. If the removal and resetting can be done on a cloudy day, so much the better. Not even the fine, fibrous rootlets should be allowed to become dry. It would be well if the hole could be prepared in advance for the reception of the tree. Let it be broad enough to receive the roots without any bending or cramping. It may better be too broad than too narrow and a little deeper around the margin than in the center. It would be better if deep enough, that it receive a layer of rich garden soil or leaf mold three or four inches thick on which the tree may stand. A pile of similar soil should be ready as soon as the tree is put in position to sift over its roots and pack down upon and between them. Settle this soil still more about the fibrous roots by giving it a copious sprinkling with a watering pot. Finally, fill the hole with soil and cover the surface with a layer of manure, to act as a mulch and keep the soil moist about the roots. Put no manure in the hole nor in contact with the roots. Plant no tree so near the schoolhouse that in after years it will unduly shade the windows and darken the schoolroom. Do not plant the trees too close to each other. Give them an abundance of room to form broad, well shaped heads. Before taking up the tree to be transplanted, it is well to cut away any slender, feeble, irregular or superfluous branches, in order to reduce the head to good shape and to diminish the demand that would otherwise be made upon the roots for support at a time when they are not able to supply the usual amount of moisture and nourishment. 


\section{HOW TO PLANT A TREE}

The following, from "The Tree Book," by Doubleday, Page \& Co., presents briefly and forcibly the steps to be taken in the proper planting of a tree:

1. Dig the hole wider and deeper than the tree requires. If the tree just fits into the socket the tips of the roots will meet a hard wall which

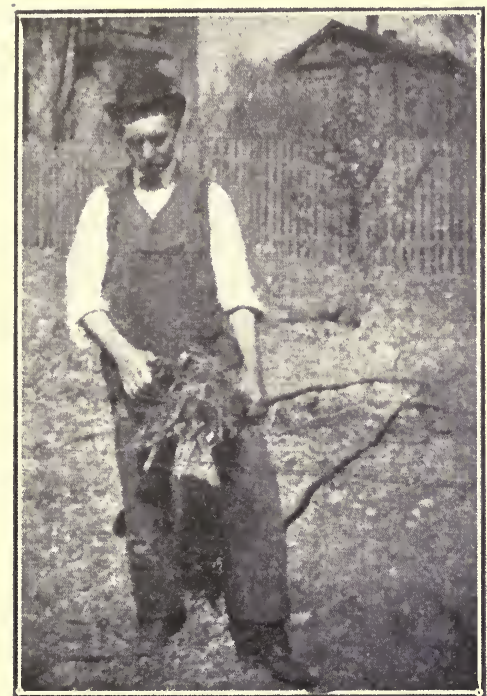

they are too delicate to penetrate, hold fast to or feed in.

2. Be sure that the surface soil is hoarded at one side when the hole is dug. This soil is mellow and full of plant food. The under soil is harder and more barren. Some rich garden soil can well be brought over and used instead of this subsoil.

3. Take up as large a root-system as possible with the tree you dig. The smaller the ball of earth the greater the loss of feeding roots and the danger of starvation to the tree.

4. Trim all torn and broken roots with a sharp knife. A ragged wound below or above ground is slow and uncertain in healing. A clean, slanting

cut heals soonest and surest.

5. Set the tree on a bed of mellow soil with all its roots spread naturally.

6 . Let the level be the same as before. The tree's roots must be planted, but not buried too deep to breathe. A stick laid across the hole at the ground level will indicate where the tree "collar" should be.

7. Sift rich earth, free from clods, among the roots. Hold the tree erect and firm; lift it a little to make sure the spaces are well filled underneath. Pack it well down with your foot.

8. If in the growing season, pour in water and let it settle away. This establishes contact between root hairs and soil particles, and dissolves plant food for absorption. If the tree is dormant do not water it.

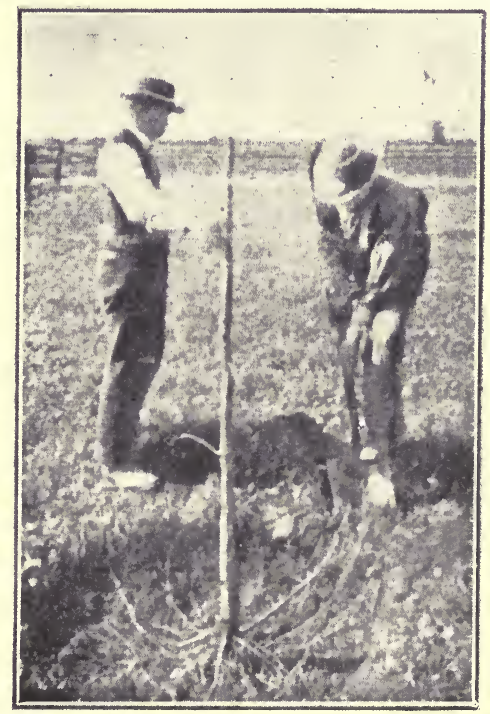


9. Fill the hole with dirt. Tramp in well as filling goes on. Heap it somewhat to allow for settling. If subsoil is used, put it on last. Make the tree firm in its place.

10. Prune the top to a few main branches and shorten these. This applies to a sapling of a few years whose head you are able to form.

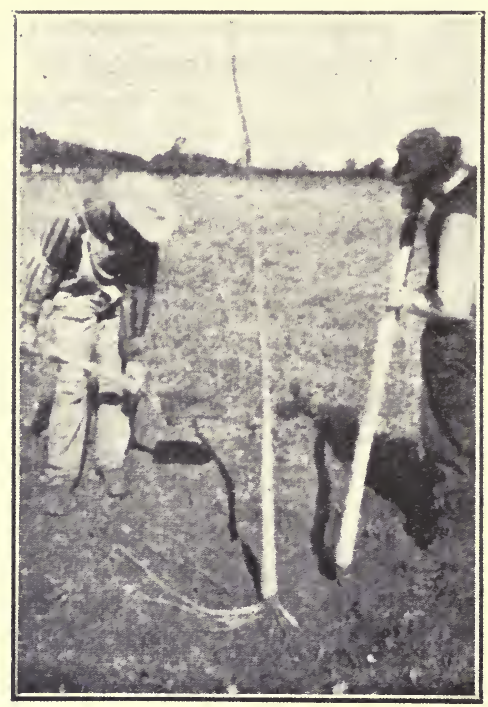

Older trees should also be pruned to balance the loss of roots. Otherwise transpiration of water from the foliage would be so great as to overtax its roots, not yet established in the new place. Nany trees die from this abuse. People can not bear to cut back the handsome top though a handsomer one is soon supplied by following this reasonable rule.

11. Water the tree frequently as it first starts. A thorough soaking of all the roots, not a mere sprinkling of the surface soil, is needed. Continuous growth depends on moisture in the soil. Drainage will remove the surplus water.

12. Keep the surface soil free from cakes or cracks. This prevents excessive evaporation. Do not stir the soil deep enough to disturb the roots. Keep out grass and weeds.

\section{* $*$ \\ TEACHERS, PLANT TREES!}

Teachers, plant trees! They will reward you. We can not all find time nor well afford to build anything like the triumphal arches of the Cæsars to commemorate our deeds upon the school ground, but we can easily plant a few trees in our school yard which will stand as living monuments to what we accomplished, long after our every other endeavor has been wrapped in the paper of recollection, perfumed by the lavender of memory, and long corered by the dust of time.

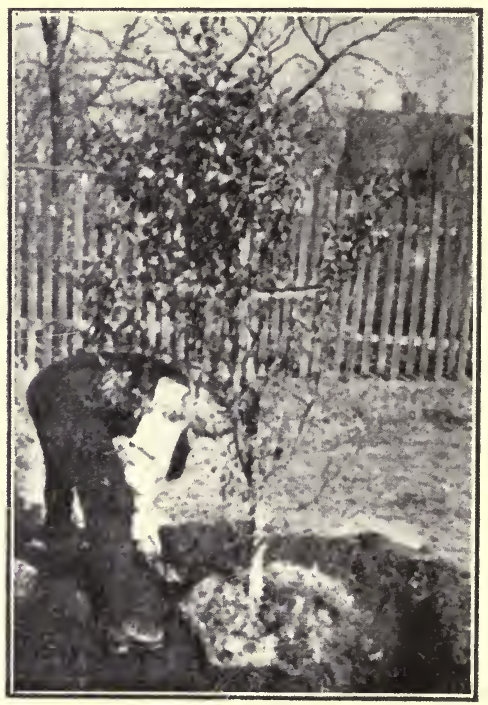




\section{TREES FOR PLANTING}

ACACIA BLACK-WOOD-An evergreen of value in semi-arid regions; produces symmetrical crown and shapely trunk.

CATALPA HARDY-Grows rapidly, pretty foliage and bloom, durable wood. Must be protected from high winds and stock, branches brittle.

Eцм, Sсотсн-Splendid tree for street use; foliage luxuriant and comes early; trunk round and stout; trees symmetrical. Probably best of elm varieties.

ELM, CORK-A hardy and vigorous tree of great value for roadside or sidewalk planting. Shapely and easily grown in Northern California.

Grevillea- A well balanced tree of divided leaves and sprays of brilliant blossoms; used with much success in Southern California. Somewhat unsightly as it grows old.

Gun, Blue-Commonest of the many varieties of Eucalyptus; tall, notel for curative properties and value of wood; not good for school yards except.as wind break, on account of spreading roots.

Hawthorn, ENGLish-An attractive small tree.

Locust-IWood is hard, close-grained and strong; makes splendid shade tree, and is suitable for large playgrounds; bears a profusion of fragrant flowers.

LINDEN-An excellent tree for the coast section.

Maple, California-A native tree, broad leaved, clean in growth, of quick growth, adapted to all soils, though doing best in loam.

Magnolia-A thrifty tree with remarkably fine leaves and waxy blossoms. A decorative tree.

Poplar, Carolina-Grows well, is fine appearing and very shapely.

Poplar, Silver - So called from silvered leaves which flash with every breeze. Ornamental, hardy and of striking appearance.

PECAN-Adapted to the interior valleys where it acquires great size.

PALMS - A great variety of palms; of great decorative value, of rather slow growth, require much room. Suitable for lawns, wide avenues or parked spaces, giving a tropic air to the landscape.

Pepper-Especially adapted to Southern California; delicate Nile green foliage, clusters of brilliant red berries, and graceful, drooping foliage make it an excellent tree for planting. Stands drouth well, does best in hot climate, and is perhaps the best of all shade trees south of Sacramento.

UnBrella - Affords good summer shade, has crown of dense foliage, which in autumn takes on beautiful hues. Especially adapted to San Joaquin Valley and the south.

WaLnUt, California - Another tree native to the soil; a thriving, productive and easily propagated tree. The English Walnut is also a good type of tree. 


\section{TREES, SHRUBS, AND VINES}

\section{SUITABLE FOR CALIFORNIA SCHOOL GROUNDS.}

By Dr. HARVEY HaLL, of the University of California.

\section{TREES}

ACACIAs are eminently adapted to school grounds; rapid growers not particular as to soil, hardy, easily cared for. Of the feathery-leaved sorts Acacia mollissima is perhaps the best and develops into a larger shade tree with an abundance of yellow flowers in early spring. $A$. melanoxylon, a broad-leaved species, has a more dense foliage and is of rather somber aspect. A. baileyana is very handsome as a lawn tree; growth erect, foliage silvery-white.

Albizzia is often mistaken for Acacia, which it resembles, but it is even more rapid in its growth, endures considerable drought, and has larger compound leaves.

Australian Bush-cherry is a most dignified evergreen tree, carrying its head high, but with gracefully drooping sprays of rather small glossy-green leaves. The edible fruits may be objectionable in a tree for school yards.

CAMPHOR trees are suitable for districts of little or no frost. It will furnish material for demonstrating the commercial preparation of camphor.

Coтtonwoons are large deciduous trees suitable for playgrounds where shade during the summer months is desired. Best grown on low ground where the subsoil is moist. Easy and rapid.

LinDExs are among the most hospitable of all, their whole aspect being one of welcome. The generously broad leaves furnish abundant shade except in winter. Hardy and easily grown. White and silver linden is the best.

MAPLEs are well known. Where a large tree is needed our native Broad-leaved Maple should be used. The Silver Maple is somewhat less spreading but more handsome.

MAYten "Smilax Tree," the slender parent twigs and small oval leaves, simulating sprays of smilax. A slow-grower, eventually forming a tall tree. Evergreen and perfectly hardy.

OAks are slow growers, but a few should be planted, where possible, as a legacy for future generations. The native evergreen Field Oak, or Encina, is one of the best for shade purposes.

PePper trees are always satisfactory. Care should be taken in planting to see that only staminate trees are used, since the berries of pistillate trees cause objectionable litter. 
Planes are to be considered along with Maples, having the same general characteristics. The Oriental Plane, related to our native so-called Sycamore, is by far the best sort, forming as it does a symmetrical round-topped tree.

Moreton Bay Fig. This is sometimes called Rubber Tree, and in fact may be considered as one sort of rubber tree. It grows to immense size with widely spreading branches which will eventually throw down aërial roots, as in the case of the noted Banyan. Suitable only for coast counties.

TAMARISK. Here we have an easily grown beautiful tree particularly adapted to hot dry climates. The soil should be kept failly moist if rapid growth is desired, but the tops will endure the hottest blasts of our deserts. The feathery, spray-like foliage and rose-colored flowers especially commend it.

\section{SHRUBS}

BotTre-Brushes are so named because of the odd shape assumed by the brilliant red flower clusters. Eminently adapted to dry situations and stand pruning well. Callistemon speciosus is the most showy.

Cassia. An evergreen loosely branched plant with showy yellow blossoms most of the year. Requires but little attention, is perfectly hardy, and a very rapid grower.

Catalina Island Cherry, a native son, is one of the very best evergreen shrubs, largely because of its glossy green foliage, which remains clean even to the end of a long dry season. The flowers are rather small, but are followed by large purple cherries, which, however, are scarcely edible. Evergreen.

Chorsya is an aristocratic little shrub with glossy-green leaves and beautiful flowers, resembling orange blossoms.

Coprosma baUeri is a rather ungainly member, but its bright green leaves are as glossy as though varnished. The breathing pores are collected into minute depressions which may be seen on the back of the leaf. This is to protect them from the drying action of the hot winds, for the species is a native of the New Zealand deserts; evergreen and a slow grower.

Duranta and Plumbago, yield blue flowers in masses.

Escallonia is much used in all parts of California. It is a rather coarse shrub, but is easily grown. The deep green leaves and red or white flowers are pleasing.

Lion's EAR will make a good showing the first season; bushy, with showy scarlet flowers in whorls. 
Pittosponums are plants of many sorts. They are easily grown and several of them produce very fragrant blossoms. Some are adapted to hedge planting, others form shrubs, still others become large trees.

Privet is a tall, very hardy shrub with small white flowers in fragrant clusters, but most prized for the beauty and persistence of its foliage. The so-called California Privet is capital for trimmed hedges.

Photinia is a large, rounded shrub with large, glossy leaves, some of which assume beautiful shades of pink and red, very conspicuous in the mass of green foliage. Unusual, but one of the best.

\section{VINES}

Australian Pea Vine. A rapidly growing vine particularly suitable for covering outbuildings and for screens. The small leaves persist throughout the winter. Flowers showy, pea-like in shape, magenta.

Ivy of several sorts is grown with great success in California. The English Ivy, which is the most easily grown, requires no care, is splendid for covering old stumps or outbuildings and as a substitute for lawns on embankments. The evergreen leaf is broad and angular, thick and of a dark green color. The Boston Ivy is more dainty, of a light green color, passing through all shades of pink to scarlet as winter advances. It is capital for brick or concrete walls and chimneys, but also climbs over frame buildings. The Virginia Creeper is sometimes confused with Boston Ivy, but differs in having compound leaves. It may be used the same as Boston Ivy. The German Ivy is the most rapidly growing of all, and is particularly suitable for screens. It does not cling to walls as do the other sorts.

Kudzu-vine. Suitable for large arbors or screens where foliage is desired only from spring to late summer. Very rapid grower, a single plant covering a trellis twelve feet high and twice as long within a few months. Leaves large, flowers inconspicuous. The immense root yields well.

PASsion Vines are perhaps the most rapidly growing of all except Kudzu, but their foliage is so heavy and dense that wooden buildings covered by them are subject to decay in rainy portions of the State.

"Potato Vine" is a misleading name for Solanum jasminoides a common white-flowered vine. It is a very fast grower, free bloomer, and easily obtained, but the stems are inclined to become straggly. Solanum rantonetix, a recent introduction, now offered by a few nurserymen, is much superior. It is blue-flowered.

Trumpet Creeper may be trained either as a bush or as a vine. Its rapid growth, pleasing foliage (of a clean, lively green color) and brilliant orange colored blossoms make it a favorite for exposed places, particularly on walls and pergolas. 


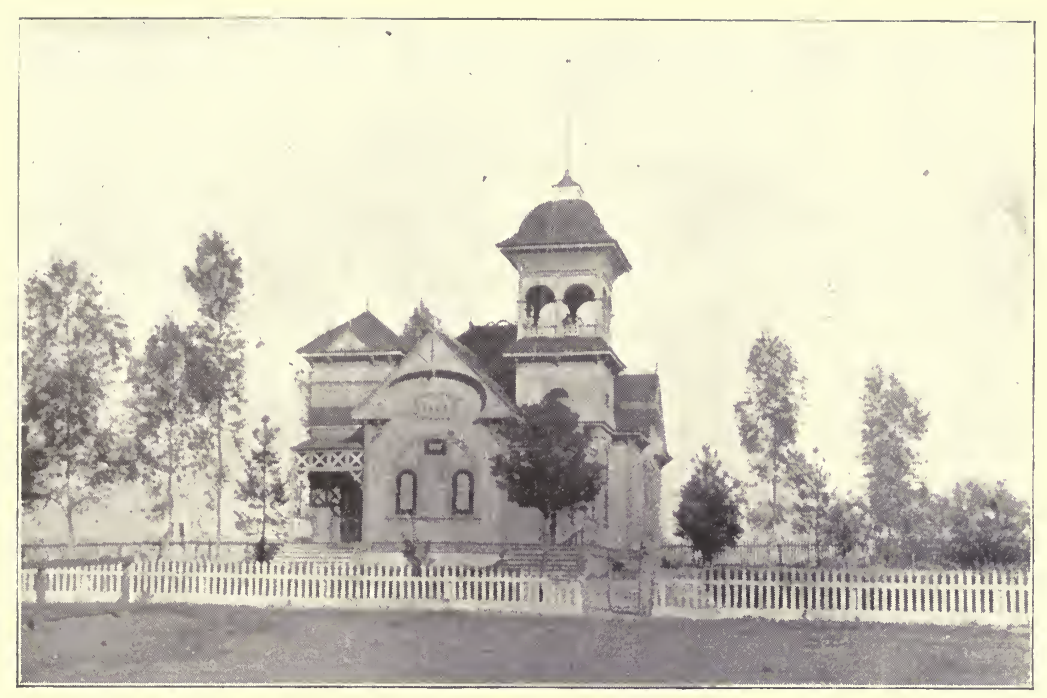

$\mathrm{H}$ $\mathrm{ERE}$ is a picture with a history. It is a photograph of a little rural school away down in southern California. I knew it well. It was in an almost rainless region, with scanty vegetation depending on irrigation. The school was on top of a dry hill, where water for irrigation was impossible. The very idea of raising trees there was absurd.

But old man Wright was one of the trustees, and he loved the school. He dreamed of it adorned by verdant shrubbery. He planted trees anyhow, despite discouragements. And through the long, hot summer season he hauled water to them with a barrel on a sled. In time the trees struck root so deep they could take care of themselves without the old man's barrel. And the school became a beautiful place, admired by all who passed that way, a pleasure in a desert land, the pride of the people. Trustee Wright has been dead now for lo, these many years. But the beautiful school on the hilltop with its waving trees is a monument to his memory. Isn't it better than granite shaft or marble urn?

Now what's a story without a moral? The moral of this one is that there's no excuse for squalid, bare, desolate, God-forsaken school grounds anywhere in the length and breadth of this rich and splendid State. When you see such a one it is a glaring sign that there is no one there who loves the school. It is a reproach upon the whole community. For shame! Why, it would be better for little Betty Jones to plant a tiny acorn or a walnut and carry water to it in a tomato can than to leave the public school naked to the world. 


\section{IN THE SHADE OF THE OAKS}

Trees are gracious things. They give their blessing to rich and poor alike. Little children are attracted to them spontaneously. They love to play their games beneath the grateful shade. They gain strength and courage by climbing among the sturdy branches.

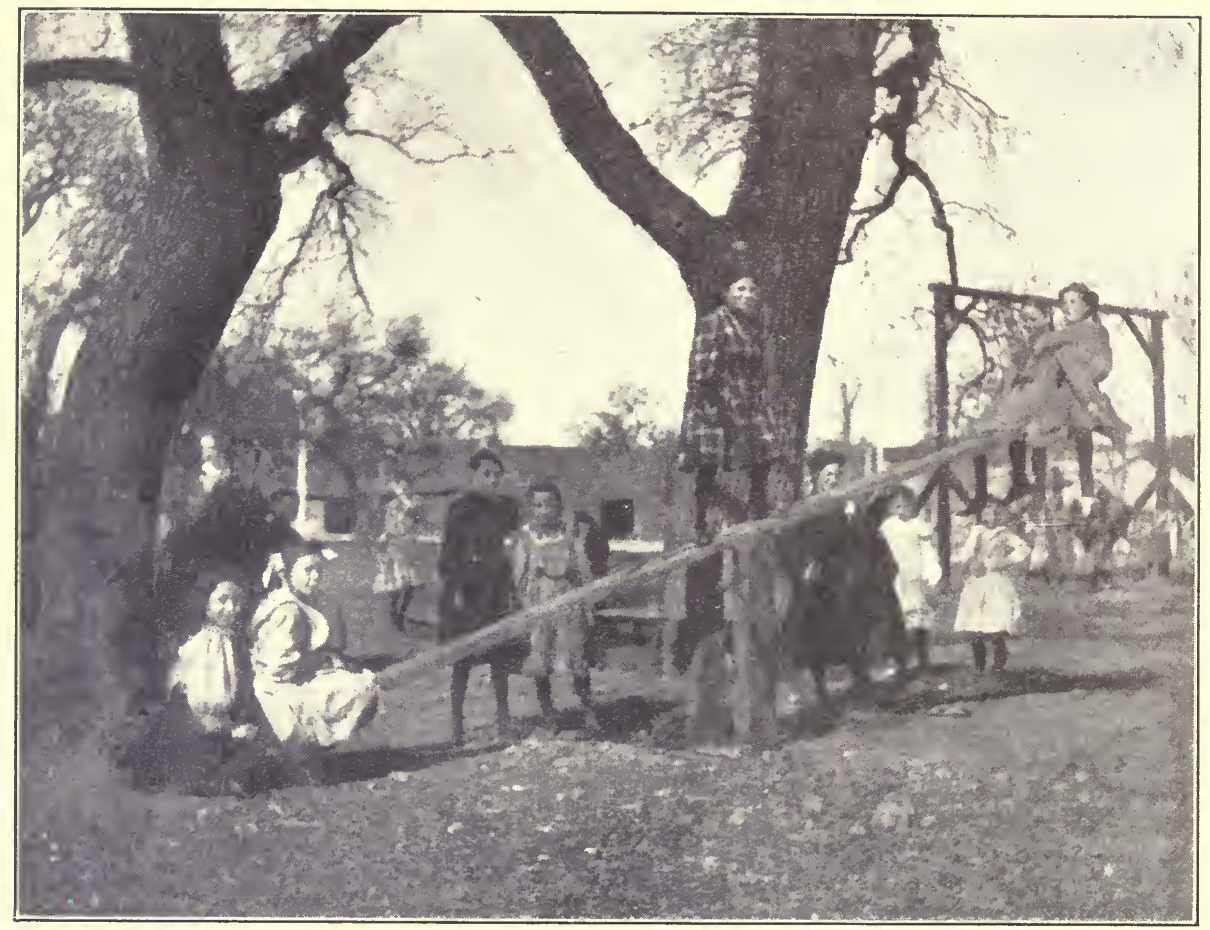

Fortunate the school like this one in Napa County that has some of the original forest monarchs on its grounds; great trees round which the children's school life revolves, and which linger in their minds as pleasant memories in all their later years.

And then, how fortunate again that it is so easy in California to raise some giant trees when there are none naturally about the school.

Plant some! Plant them now, not in the sweet bye and bye. Plant a few now, so they'll be growing while you are thinking about the big things for the future. Plant the ones you know will grow at that place. Plant them so they can't be killed by stock or children. Plant them so they'll be cared for through the summer. One or two great trees, growing luxuriantly are better for than a hundred neglected starvelings. One big fine tree, with room for swings and teeter boards, with place for enjoying luncheons in the shade-just one-will make the difference between desolation and good cheer. And where is the spot in all California that will confess its soil so sterile, its people so poor in spirit that they can not grow even one tree? 


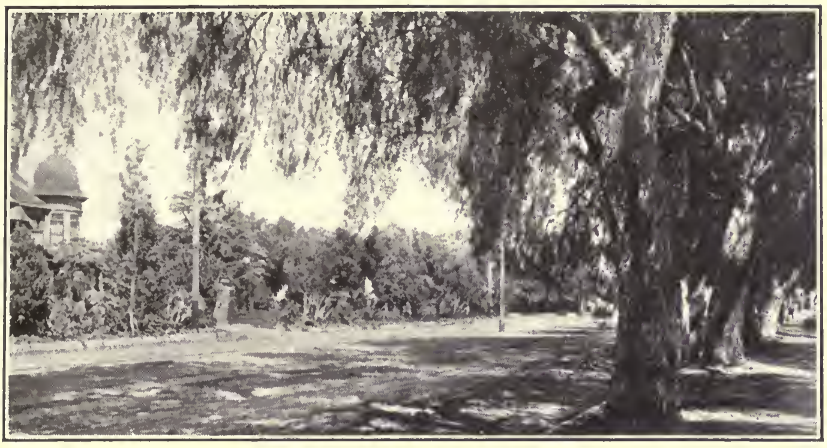

EVERY school in the State should have at least one tree. If after three years of Arbor Day observances not one tree is growing, it is a discredit and a reproach to the pupils, to the teacher, and to the Trustees. There can be no sufficient found if sought for.

One may say, "Oh, there is no fence round our school, and it is no use to plant, for the stock will destroy the trees." True, but it wouldn't hurt that school and that teacher to get four posts, some boards and wire to build a fence to protect one tree. A nice pepper, or cottonwood, or umbrella, that had been generously cared for for three years would make quite an oasis in your desolation.

Another will remark, "Oh, we have no water on our schoolgrounds, and we don't believe in planting things to die." Very good; but one of the handsomest school yards in the State never had any water but what one of the trustees hauled in a barrel, without pay.

There is a picture of it in another part of this Manual. A lively school would find a way to make one tree grow freely and luxuriantly, even if they had to carry water in a tin cup to do it.

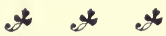

Others exclaim, "We are not sure the school will remain here-there is talk of a change-no use to plant anything until we see." It would not hurt the school to raise a tree or two any how; the children would be better off and the world would be none the worse even if you did move away and leave them. Plant a tree; it will be growing while you sleep. An Arbor Day program in a school without a tree is Faith without Works; and Faith without Works is dead. 


\section{WITH THE TEACHER}

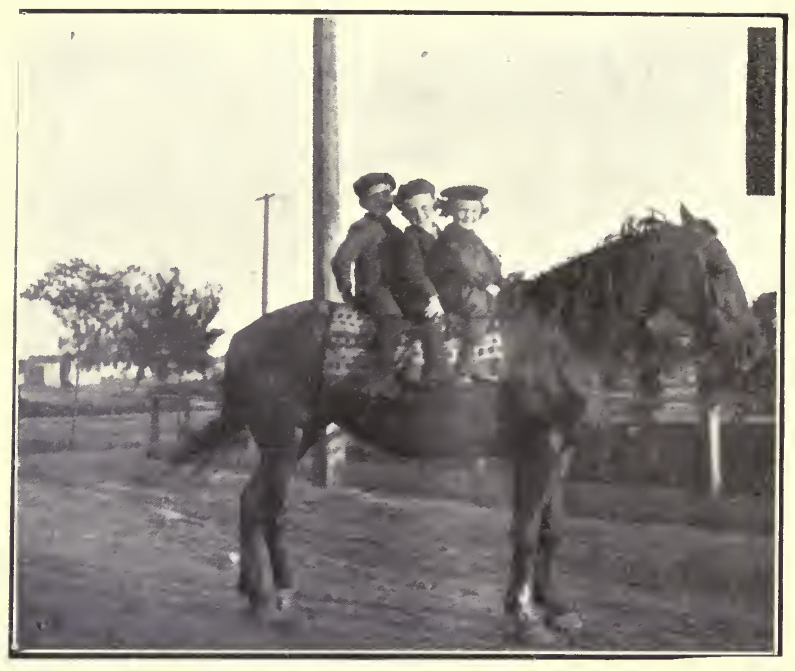

On the Way to School.
T IS a matter of common observation that neat and orderly surroundings tend to influence man's development and moral character for good. Business men, men who own large ranches, the corporations, and the railroads all recognize these principles. Railroads spend money in planting and caring for little

parks at almost every station. They cultivate all kinds of flowers and ornamental shrubs and trees. They keep everything in order around the depots. Board and iron and all other materials are carefully piled away where they belong. There is no return in money from most of this work. But the influence on the employés of the railroad is most beneficial. 'They are taught by this method that everything must be caretully attended to on account of the sacredness of human life. People would not long patronize a railroad where every thing was lying around in a loose and shiftless condition. They would most severely and rightfully judge that the moral condition, or regard for human life would be as bad as the physical conditions. Therefore, we feel that we can not easily become too enthusiastic over the improvement of school grounds.

\section{* $*$ *}

Work for the improvement of your school surroundings, and you work for the benefit of education's cause. Be not discouraged. Rather be encouraged by the work already done. "Accuse not Nature, she hath done her part; do thou but thine."

\section{DO}

Plant shrubs, vines and trees.

Pick up loose paper.

Burn or destroy rubbish.

Destroy weeds.

\section{$* * *$}

\section{DON'T}

Mark walls and buildings.

Injure shade trees or flower beds. Spit on the floors and sidewalks. Throw paper and fruit skins on the sidewalk or ground. 
Perhaps you have tried to do Arbor Day work and have failed. To you we would say, try once again, and yet once again after that, if it be necessary. To you who have tried and in the face of discouragement have succeeded in beautifying either the school ground or the school interior, we extend our congratulations. Your work has been a worthy one, and its value, while probably not apparent in dollars and cents, can not be estimated. It lies in the germ which has been planted in the minds of those who have gone forth from your school to take a part in life's busy drama, or are elected to go forth in the future from those surroundings which you have contributed towards making beautiful, refining, valuable.

One impulse from the vernal wood

Nay teach you more of man,

Of moral evil and of good,

Than all the sages can.

Arbor day is often made a convenient season for clearing up the school grounds and yards, for repairing the walks and fences, for trimming the hedges, shrubs, and trees, and for carting off the unsightly quantities of débris always collecting thereon. Such work is always necessary, and it is better than nothing, of course, but it should be followed by some actire constructive Arbor Day work, the creation of something new.

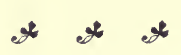

J F THE observance of Arhor Day ends with the exercises in the schoolroom, however pleasant and entertaining they may be, the real purpose of the day will not have been accomplished. There should be some practical work not only in and around the school building, but the influence must reach the home surroundings as well. In some schools in former years, every pupil has pledged himself to plant something at home, either a tree, shrub, flower, or something in the garden; and the interesting stories that could be told of the results of this work would fill a book. The true spirit of Arbor Day is the influence on the life and character of the pupils as exemplified in practical work. A love for the beautiful as well as a desire for the more useful should be cultivated, and all that pertains to material prosperity should be made prominent. It is not always the homes of the more wealthy but the homes surrounded by indications of taste, culture, and refinement that are the most attractive. These things being emphasized, the youth of our State will have better ideals and will be prepared to take higher standing as citizens of our commonwealth. Let us then make Arbor Day practical by doing some real planting and by learning something useful about trees and their relation to human life. 


\section{TWO TEACHERS AND ARBOR DAY}

\section{ONE TEACHER.}

I have in mind one teacher, who a few days before Arbor Day, assigned the different parts just as they were suggested in the printed program. On Arbor Day she had a perfunctory recitation of the different selections; after this all gathered around a little hole dug in the hard ground and planted one small tree. This closed the work for the day, and the pupils felt that the principal thing about Arbor Day was that they were dismissed an hour earlier than usual. The pupil's mind unconsciously receives the thoughts of the teacher. As she thinks, so to a certain extent the pupil thinks and acts. This the teacher can not help, even if she would.

\section{THE OTHER TEACHER.}

I have in mind another teacher who very early in the spring brought to the school a few bulbs, told her pupils about them, and planted them in pots at different times. All became interested in watching for the green sprouts to appear, and in watching the daily progress of these plants until they bloomed. Gradually the pupils were interested and taught, day by day, from this little beginning about flowers. Some time before Arbor Day a few of the larger boys spaded up the plot of ground set aside for their park. This was then fertilized by materials brought from a neighboring barnyard, and on Arbor Day a number of rose bushes and choice trees were set out. Then the program was given, and the pupils felt a special interest in each selection. The work did not stop there, for the boys and girls began to ask for books giving particular instruction in caring for plants. Then some of them began to ask the teacher's help in arranging a Hower garden for the home. Which teacher do you prefer to be? 


\section{AFTER ARBOR DAY}

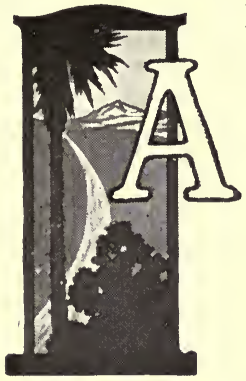

ND now we come to the most important of all-After Arbor Day. After the program has been rendered, after the trees and shrubs have been planted-what will be their fate? Is water hard to secure in your district? Will there be several long, hot, dry summer vacation months when the schoolhouse is deserted, when no one comes near to inquire into the condition of the trees planted on Arbor Day? Have trees and shrubs been planted and left to struggle for themselves, live or die, without further care?

These are but a few of the pertinent questions which the teacher must answer-and needs must answer BEFone Arbor Day, if success is to mantle her efforts. Plans must be made for months ahead; if you begin the work, carry it through. "Not how many trees planted, but how many trees live," should be your watchword and battle cry. It is labor lost to plant trees and then abandon them to merciless climatic conditions, to become the prey of vagrant cow or horse, to die through sheer neglect. The teacher in the southland will have a greater task before him than will his northern fellow teacher,for in the north-

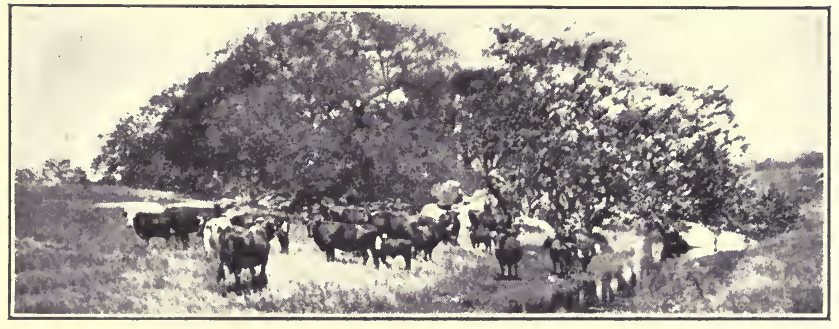
land rainfall is more plentiful, summer exactions less rigorous, and vegetation more prolific,-but the greater renown will attach his successful efforts.

Arrange to have the janitor, a trustee, some patron, or a boy come during the summer months and water the trees and shrubs; see that stock is kept off the premises, enrich the soil, and cultivate where necessary. A portion of the money set aside to pay the regular janitor (see Sec. 1617, Subd. 7, California School Law) could be used to pay for this vacation care, if no one can be secured to do the work and do it faithfully without compensation.

Water supply, cultivation and care of trees and shrubs, AFTER ARBOR DAY, are the important factors you should look to if Arbor Day planting is to be of effect. It is difficult to decide which has the worst influence upon the pupil-a barren school ground, or dead stumps and decaying shrubs; sad monuments to a lost cause, reminders of a poorly planned campaign. 


\section{MOUNTAIN VIEW DISTRICT SCHOOL}

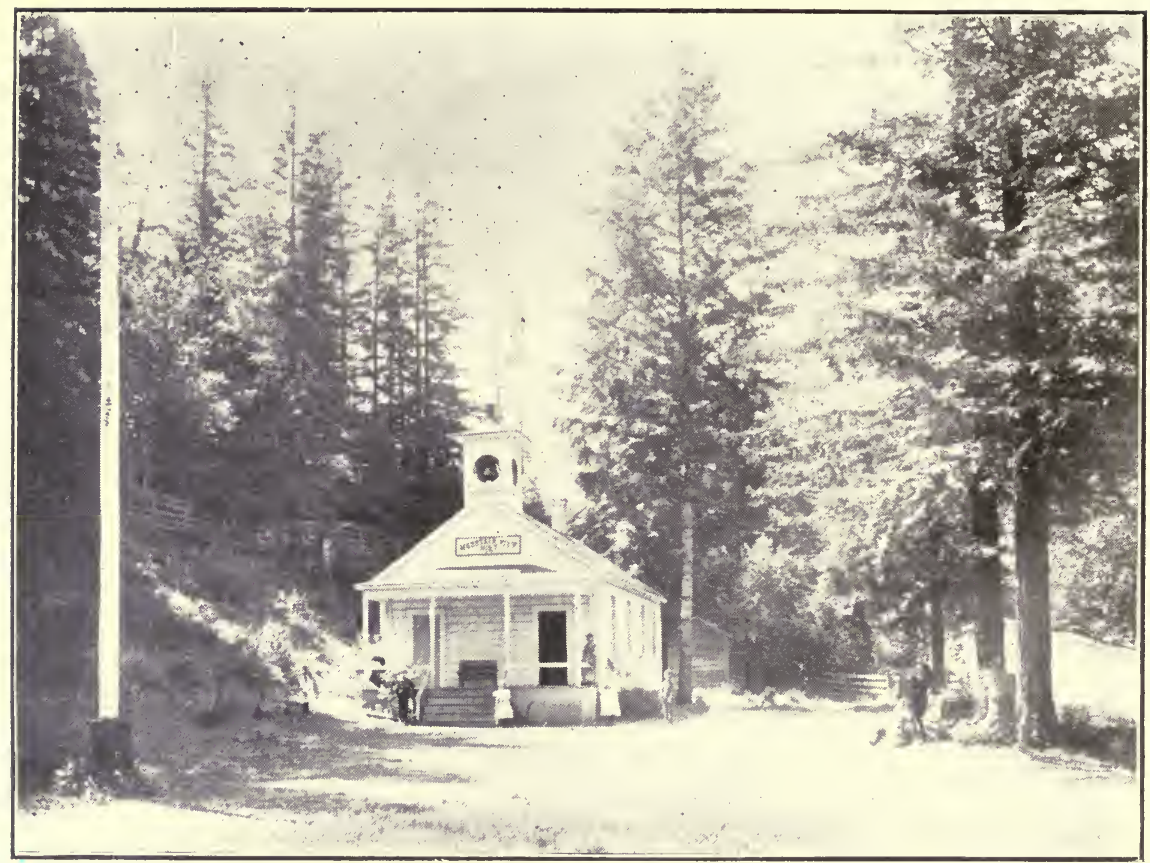

MOLNTAIN VIEW DISTRICT SCHOOL

The mellow toned little bell on the Mountain View schoolhouse, located near Forestrille, in Sonoma County, calls the pupils to a naturally adorned playground. The natural arrangement of the trees gives shade in summer, affords protection from wintry blasts, and permits plenty of light to enter the busy schoolroom. From the native flag pole in the foreground Old Glory flies above this gem in Nature's setting. 


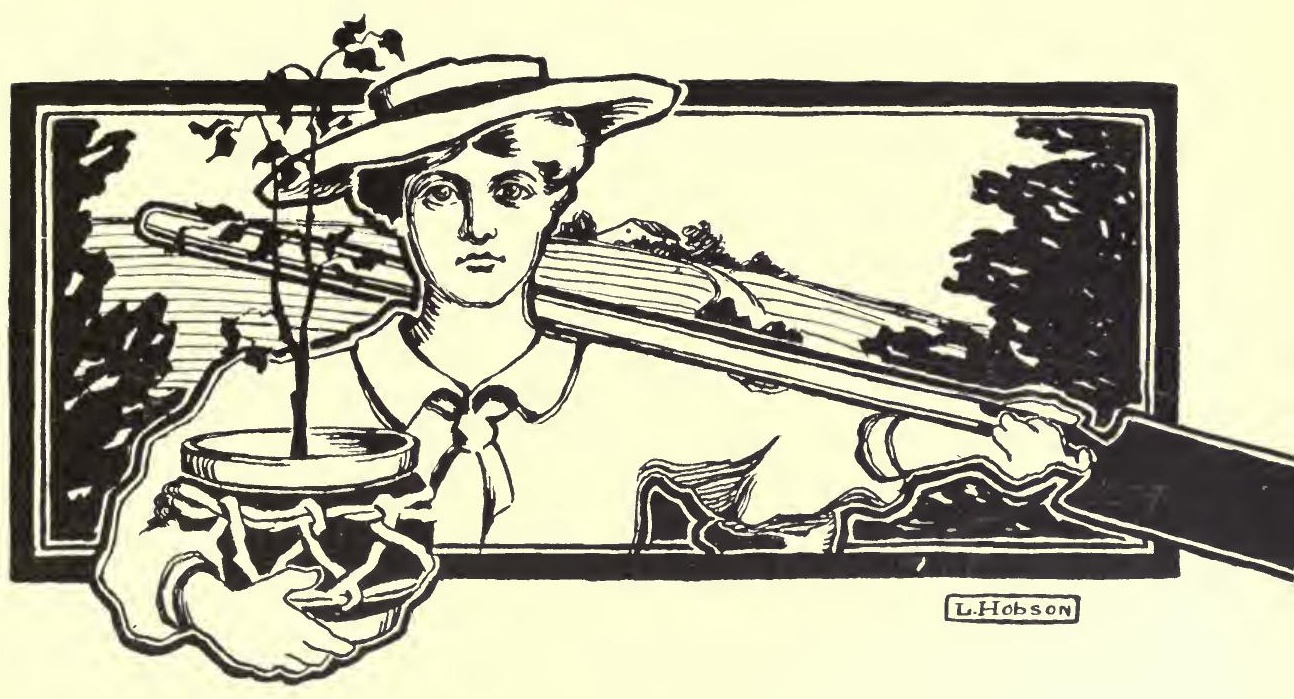

FOR THE ARBOR DAY PROGRAM

W would suggest that you find out as early as possible the date
for the observance of Arbor Day, and begin to prepare your
plan and your program.

Start in at once to arouse an interest in Arbor Day. Find out who will furnish trees, shrubs or seeds, or where they may be procured. Clean up the yard thoroughly and destroy all rubbish.

For some weeks before Arbor Day comes use your morning exercises now and then, or your Friday afternoons, to read or talk to the pupils about Arbor Day, plants, historical trees or interest awakening stories.

Talk with your trustees and various patrons of the school about the subject and try to arrange for a basket picnic; plan to have an all-day entertainment, if possible, planting the trees in the forenoon and holding the entertainment in the schoolroom during the afternoon. The teacher will be the best judge, taking in to consideration all local conditions, of the conduct of the day's work.

Just before Arbor Day prepare invitations for everyone in the district, if practicable. Cut

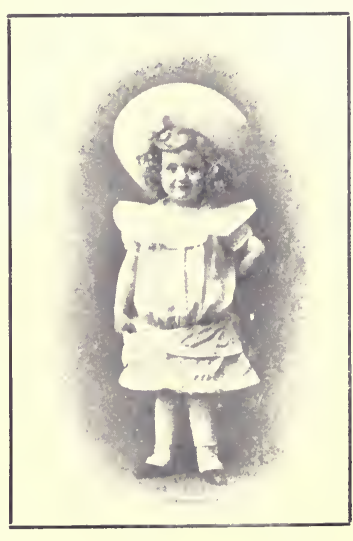
paper in the form of a large autumn leaf, and have the best writers among your pupils assist in writing the invitations, which should be short and to the point. 


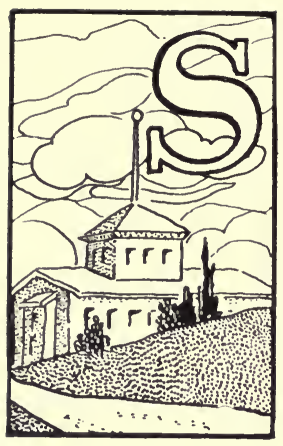

\section{OME SUGGESTIONS}

Decorate the schoolroom with flowers, branches of trees and greenery if possible to secure them. Use bunting, pictures of trees, birds and pretty homes to cover the walls. Write or print short and appropriate Arbor Day gems on the boards. Use the flag as one of your chief decorations above the platform.

Provide plenty of good music, if possible, and give especial emphasis to poems, quotations and to reports by the pupils. Arrange for one of your patrons to address the school on the subject.

The program should be long enough to admit of variety, but not so long as to be wearisome. Give places upon it to all the pupils. Alternate the recitations and readings and musical selections.

The following suggested program is intended simply as a guide; substitute other numbers for the ones given; shorten, lengthen, add to or take from-do what you think best to make your program attractive. Try to make things go with a snap and a vim.

After you have finished with this Arbor Day Manual put it in the school library with the other books of the district. It is to be kept for future reference.

\section{A PROGRAM}

Song- "The Planting Song."

Salute to the Flag-By the pupils standing and giving in concert: "I pledge allegiance to my flag and to the republic for which it stands. One nation, indivisible, with liberty and justice for all." Reading-(a) The Origin and History of Arbor Day.

(b) President Roosevelt's Message to the School Children of the United States.

Remarks-By the Teacher.

What Arbor Day means to pupils and patrons. Effect of the work on future citizenship and progress. What has been done in the past. Needs of the district to carry on work; fences; water supply; summer care; paint; coïperation. See "With the Teacher" and "After Arbor Day."

Pecitation- $-(a)$ "Plant a Tree."

(b) "Our Three Favorites."

Song of Dedication-"An Arbor Day Tree."

Dialogue- $(a)$ "The Trees and the Seasons."

(b) "What the Trees Teach Us."

Essay - (a) The State Flower of California.

(b) State and National Flowers.

(c) What We Owe to the Trees.

(d) Our Most Useful Trees. 
Recitation-(a) "Woodman, Spare That Tree."

(b) "Three Trees."

Dialogue- $(a)$ "Which Shall It Be?"

(b) "Why We Keep Arbor Day."

Song-"Arbor Day."

Reading- $(a)$ "A Wonderful Tree."

(b) "From the Forest."

Roll Call-Each pupil to rise at call of his name and give a quotation suited to Arbor Day.

Recitation and Pantomime- "Three Little Trees."

Recitation-"Historic Trees." By nine pupils. Song-"Arbor Day March."

Address by a speaker chosen for the occasion. (Patron, trustee, clerk of school board, minister, county superintendent, or other speaker.)

Song-" Springtime."

Closing Remarks by the Teacher.

Song-"America." Audience and school standing.

(NoTk.-Several selections are given for each recitation, reading and dialogue; choose the one best adapted to your pupils and if necessary rearrange the order in which the different numbers come. A short Good program is much more effective than a poor long one. A thing not done well is better not done at all.)
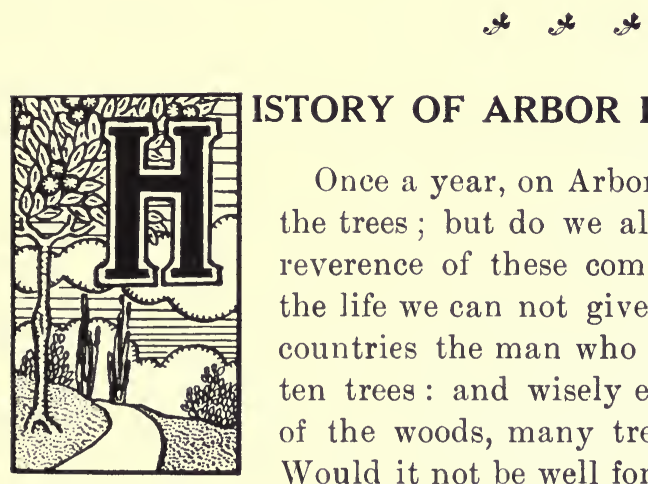

\section{ISTORY OF ARBOR DAY}

Once a year, on Arbor Day, we talk and sing about the trees; but do we all the year keep the spirit of reverence of these comrades of the forest, guarding the life we can not give again? In some European countries the man who cuts down a tree must plant ten trees: and wisely enough, because in the chances of the woods, many trees die for one that prospers. Would it not be well for us Americans to offer hostage to the future by thus seeding the ground we desolate? And would it not also be well for us to act as guardians to the fine old trees already growing green and goodly about us-to see that they are pruned and patched, if necessary? for the tree doctor can now fill a hole in a tree to check decay, as the dentist fills a hole in a tooth. Improvement Clubs and Good Government Clubs could lessen the wanton destruction of noble trees by judicious expostulation with the axman, or by crossing his palm with a few persuasive dollars-dollars that would count as an alms to posterity.

We are told that the custom of tree planting is an old one among the Germans, who in the rural districts practice a commendable habit of 
having each member of the family plant a tree at Whitsuntide, which comes forty days after Easter. The old Mexican Indians also plant trees on certain days of the years when the moon is full, naming them after their children; and the ancient Aztecs are said to have planted a tree every time a child was born, giving it the name of the child.

But to the Hon. J. Sterling Morton of Nebraska, Secretary of Agriculture in President Cleveland's cabinet, belongs the honor of instituting our American Arbor Day. Julius Sterling Morton was born in Jefferson County, New York, April 22, 1832. He was of Puritan stock, his ancestors having come from England on the Little Ann, the first ship after the Mayflower. His parents removed to Michigan when the son was still a baby. He was sent to good private schools and seminaries, and later to Michigan University, but was graduated at Union College, New York, in 1854. Immediately after completing his college course he married and removed to Nebraska, and in the following year chose Nebraska City as his permanent home, locating upon a claim half a mile square, adjacent to the town. This estate grew into the beautiful Arbor Lodge, so familiar to all lovers of the holiday founded by Mr. Morton. It was home for the remainder of his life.

It was at an annual meeting of the Nebraska State Board of Agriculture, held in the city of Lincoln, January 4, 1872, that Mr. Morton introduced the following resolution:

Resolved, That Wednesday, the 10th day of April, 1872, be and the same is hereby especially set apart and consecrated for tree planting in the state of Nebraska, and the State Board of Agriculture hereby name it Arbor Day, and to urge upon the people of the state the vital importance of tree planting, hereby offer a special premium of one hundred dollars to the agricultural society of that county in Nebraska which shall upon that day plant properly the largest number of trees; and a farm library of twentyfive dollars worth of books to that person who on that day shall plant properly in Nebraska the greatest number of trees.

The resolution was unanimously adopted. A second resolution was likewise adopted, asking the newspapers of the state to keep the matter constantly before the people until the appointed day; and the result was the planting of over a million trees in Nebraska on this first Arbor Day.

From this beginning on that western prairie the movement has spread in an ever widening circle, whose circumference to-day sweeps from the Atlantic to the Pacific.

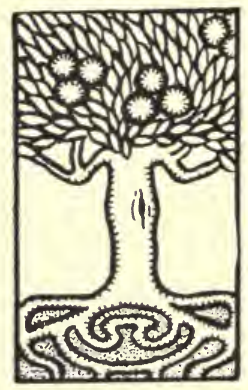




\section{PROCLAMATION OF THE PRESIDENT TO THE SCHOOL CHILDREN OF THE UNITED STATES.}

[This letter from the President of the United States would be a fine thing for one of the older pupils to deliver slowly, thoughtfully, earnestly as an oration; or four pupils could give it, one paragraph for each.]

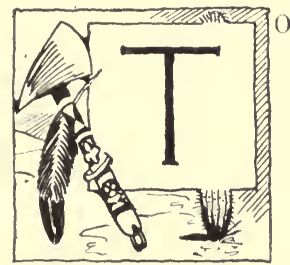

O THE SCHOOL CHILDREN OF THE INITED STATES:

Arbor Day (which means simply "Tree Day") is now observed in every State in our Union-and mainly in the schools. At various times from January to December, but chiefly in this month of April, you give a day or part of a day to special exercises and perhaps to actual tree planting, in recognition of the importance of trees to us as a Nation, and of what they yield in adornment, comfort, and useful products to the communities in which you live.

It is well that you should celebrate your Arbor Day thoughtfully, for within your lifetime the Nation's need of trees will become serious. We of an older generation can get along with what we have though with growing hardship; but in your full manhood and womanhood you will want what nature once so bountifully supplied and man so thoughtlessly destroyed; and because of that want you will reproach us, not for what we have used, but for what we have wasted.

For the nation as for the man or woman and the boy or girl, the road to success is the right use of what we have and the improvement of present opportunity. If you neglect to prepare yourselves now for the duties and responsibilities which will fall upon you later, if you do not learn the things which you will need to know when your school days are over, you will suffer the consequences. So any nation which in its youth lives only for the day, reaps without sowing, and consumes without husbanding, must expect the penalty of the prodigal, whose labor could with difficulty find him the bare means of life.

A people without children would face a hopeless future; a country without trees is almost as hopeless; forests which are so used that they can not renew themselves will soon vanish, and with them all their benefits. A true forest is not merely a storehouse full of wood, but, as it were, a factory of wood, and at the same time a reservoir of water. When you help to preserve our forests or to plant new ones you are acting the part of good citizens. The value of forestry deserves, therefore, to be taught in the schools, which aim to make good citizens of you. If your Arbor Day exercises help you to realize what benefits each one of you receives from the forests, and how by your assistance these benefits may continue, they will serve a good end.

Theodore Roosevelt.

The White House. 


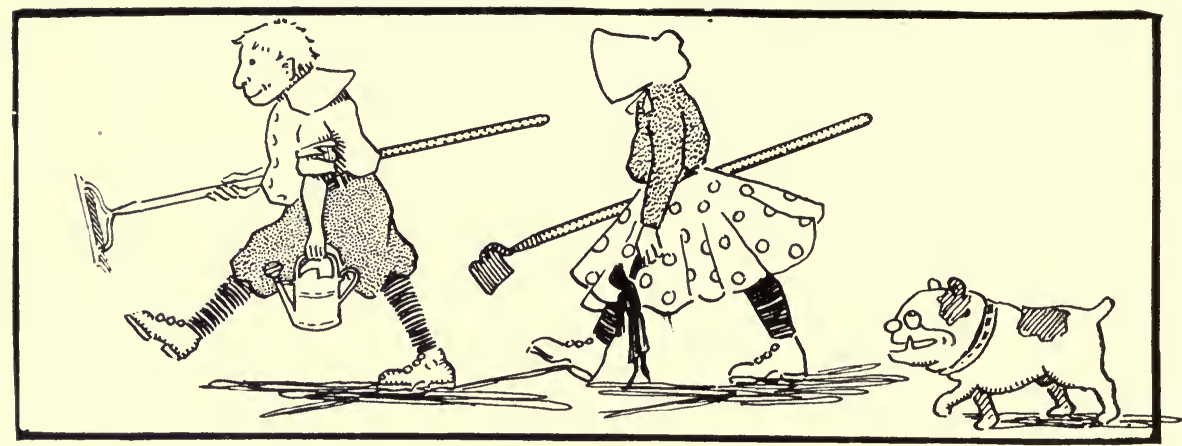

\section{PROGRAM HINTS AND HELPS}

\section{SOME FAMOUS TREES}

Certain of the pupils can find information relating to the famous trees mentioned below, and either recite a bit of verse or prose, or write a short, interesting paper. Descriptions may be given of the trees as an answer to roll call.

1-The California Big Trees.

2-The Treaty Elm of Philadelphia.

3-The Liberty Elm of Boston.

4-Washington's Elm at Cambridge.

5-The Charter Oak of Hartford.

6-The Hamilton Trees of New York.

7-The Tree from Napoleon's Grave.

8- The Cary Sycamore.

9-The Apple Tree of A ppomattox.
10-Shakespeare's Mulberry Tree.

11-The Banyan Tree of India.

12-Burgoyne's Elm.

13-The Cedars of Mt. Lebanon.

14-Arnold's Willow near West Point.

15-Magnolia Council Tree, Charleston, S. C.

16-The Cypress Tree of Montezuma.

\section{SELECTIONS}

Treaty Elm, the great elm tree beneath the shade of whose branches iVilliam Penn stood when he made his famous treaty with nineteen tribes of Indians.

Liberty Elm at Boston is another of the famous elm trees; it was planted and dedicated by a schoolmaster to the independence of the colonies, and was the rallying point for patriots before, during and after the Revolutionary War.

The Freedman's Oak, or Emancipation Oak, at Hampton, Virginia, sheltered the slaves of the region when they first heard read President Lincoln's Emancipation Proclamation.

The Cary Tree planted by Alice and Phœbe Cary in 1832; a large and beautiful sycamore seen from the Hamilton turnpike in Ohio. 


\section{HISTORIC TREES}

I. CHARTER OAK.

In history we often see

The record of a noted tree.

We'll now some history pages turn

And note what trees we there discern:

And foremost of this famous band

We think the Charter Oak should stand.

We love to read the story o'er,

How Andrus came from England's shore As governor in this new land, And ruled it with a tyrant's hand;

How, when he came to Hartford town

Demanding with a haughty frown

The charter of the people's rights,

All suddenly out went the lights;

And e'er again they re-appeared,

The charter to their hearts endeared

Lay safely in this hollow tree,

Guard of the people's liberty.

All honor, then to Wadsworth's name,

Who gave the Charter Oak its fame.

\section{LIBERTY ELM.}

Another very famous tree

Was called the Elm of Liberty.

Beneath its shade the patriots bold

For tyranny their hatred told.

Upon its branches high and free

Was often hung in effigy

Such persons as the patriots thought

Opposed the freedom which they sought.

In war time, oft beneath this tree

The people prayed for victory;

And when at last the old tree fell

There sadly rang each Boston bell.

\section{WASHINGTON ELM.}

In Cambridge there is standing yet

A tree we never should forget;

For here, equipped with sword and gun,

There stood our honored Washington,

When of the little patriot band

For freedom's cause he took command.

Despite its age - three hundred years-

Its lofty head it still uprears;

Its mighty arms extending wide,

It stands our country's boasted pride.

IV. BURGOYNE'S ELM.

When, in spite of pride, pomp and boast, Burgoyne surrendered with his host, And then was brought to Albany

A prisoner of war to be,

In gratitude for his defeat,

That day, upon the city street,

An elm was planted, which they say

Still atands in memory of that day.
V. THE TRE ITY EIM.

Within the Quaker City's realm, There stood the famous Treaty Eln.

Here, with its sheltering boughs above, Good William Penn, in peace and love,

The Indians met, and there agreed

Upon that treaty which we read

Was never broken, though no oath

Was taken-justice guiding both.

A monument now marks the ground

Where once this honored tree was found.

VI. TREE FROM NAPOLEON'S GRAVE.

Within a city of the dead,

Near Bunker Hill, just at the head

Of Cotton Mather's grave, there stands

A weeping willow which fond hands

Brought from Napoleon's grave, they say,

In St. Helena, far away.

VII. THE CARY TREE.

I'll tell you of a sycamore

And how two poet's names it bore;

Upon Ohio's soil it stands,

'Twas placed there by the childish hands

Of sister poets, and is known

As Alice and Phobe Cary's own.

One day, when little girls, they found

A sapling lying on the ground;

They planted it with tenderest care

Beside this pleasant highway, where

It grew and thrived and lived to be

To all around the Cary tree.

VIII. THE HAMILTON TREES.

In New York City proudly stand Thirteen monarchs, lofty, grand, Their branches tow'ring toward the sun

Are monuments of Hamilton, Who planted them in pride that we Had won our cause and libertyA tribute, history relates,

To the original thirteen States.

IX. RECITATION FOR SCHOOL.

We reverence these famous trees. What better monuments than these?

How fitting on each Arbor Day

That we a grateful tribute pay

To poet, statesman, author, friend,

To one whose deeds our hearts commend

As lovingly we plant a tree

Held sacred to his memory ;

A fresh memorial, as each year

New life and buds and leaves appear-

A living monumental tree,

True type of immortality. - Ada Simpson Sherwood. 


\title{
THE STATE FLOWER
}

\author{
Thy satin vesture richer is than looms \\ Of Orient weave for raiment of her kings; \\ Not dyes of olden Tyre, not precious things \\ Regathered from the long-forgotten tombs \\ Of buried empires, not the Iris plumes \\ That wave upon the tropic's myriad wings, \\ Not all proud Sheba's queenly offerings, \\ Could match the golden marvel of thy blooms.
}

- Ina D. Coolbrith.

\section{THE GOLDEN POPPY}

Russian and German scientists in the year 1818 found the Golden Poppy of California, and one of them named it after his friend Dr. Johann Frederick Eschscholtz (Eschscholtzia Californica).

The Golden Poppy, as it is commonly called, has anything but an agreeable perfume, but its wonderful coloring, and its incomparable, satin-like sheen, have been the wonder, delight, and admiration of all lovers of nature. Growing, as it does, throughout the length and breadth of the State, and hardly elsewhere, it is peculiarly typical of California, and in 1903, under an Act of the Legislature, was made the State Flower. It blooms in the greatest profusion from February until May, though specimens of the flower can be had in the lower valleys of California almost any day in the year. In the flood tide of its season, when this matchless flower raises itself above the feathery green foliage of the plant, which is tipped with a deep bronze-red,it covers acres upon acres of plains and mesas, and presents a sight which once seen is never forgotten.

The California Poppy is a brazen, garish flower. It shuns the woodland, and unsheltered, fairly revels in the warm sunlight. It possesses none of the modesty of the violet, the sweetness of the rose, nor the beauty of the lily, but, standing alone and unique, it compels our admiration because of its wonderful coloring and sheen, which refuse to be transferred by the limner's art to board or canvas. It wins its place by its transcendent beauty, and lovers of nature, having once reveled therein, the memory of it lives a lifetime.

O, Golden Poppy, Eschscholtzia, Flame Flower, La Amapola, Copa de Oro!-Cup of Gold! You are all one and the same. Born under cloudless sky; child of the summer sun and earth's unminted gold; inimitabie; sans story, sans art, sans poetry, sans perfume, sans all, save thy golden glory-we love you!-Prentiss Maslin. 


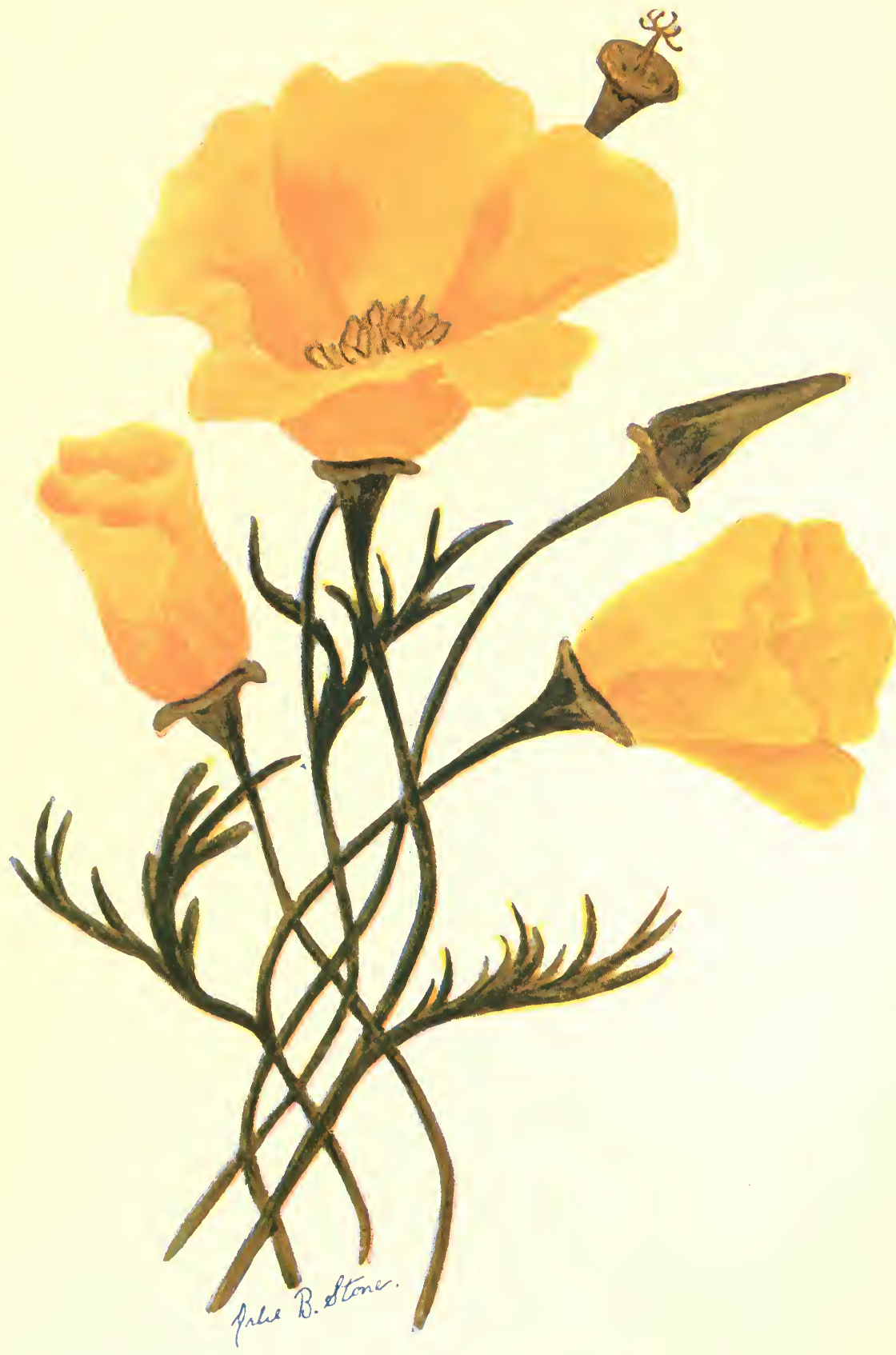

THE (IOLDEN POPPY, OR ESCHSCHOLTZIA CALIFORNICA, THE STATE FLOWER OF CALIFORNIA. 

Hiawatha's Sailing as given in Longfellow's wonderful "Hiawatha" Building the Birch Canoe-is an excellent selection to arouse interest prior to Arbor Day. Read aloud to the pupils it is probably more effective than when read by them and should be followed by a general discussion of the various trees mentioned.

\title{
STATE FLOWERS
}

Colorado-Blue and White Columbine

Arizona-Cactus

Georgia-Cherokee Rose

Kansas-Sunflower

Michigan-A pple Blossom

Minnesota-Moccasin Flower

Nevada-Sage Brush

Oregon-Oregon Grape

Vermont-Red Clover
California-Golden Poppy

Delaware-Peach Blossom

Idaho-Syringea

Maine-Pine Cone and Tassel

Montana-Bitter Root

Nebraska-Goldenrod

Oklahoma-Mistletoe

Utah-Sego Lily

Washington-Rhododendron

\section{NATIONAL FLOWERS}

Canada-Sugar Maple

China-Narcissus

England-Rose

France-Flower-de-luce

Germany-Cornflower

Greece-Violet

\author{
Japan-Chrysanthemum \\ Prussia-Linden \\ Saxony-Mignonette \\ Scotland-Thistle \\ Spain-Pomegranate \\ Holland-Orange and Tulip
}

\section{ARBOR DAY SONGS WITH FAMILIAR AIRS}

\author{
ARBOR DAY. \\ By Seymore S. Short. \\ (Air: "My Maryland.")
}

Again we come this day to greet,

Arbor Day, sweet Arbor Day,

With willing hands and nimble feet,

Arbor Day, sweet Arbor Day.

No sweeter theme our time can claim,

No grander deed points us to fame,

No day more proud than this we name,

Arhor Day, dear Arbor Day.

Bring forth the trees. Prepare the earth

For Arbor Day, sweet Arbor Day.

With song we celebrate the birth

Of Arbor Day, sweet Arbor Day.

And when our joyful task is done,

And we our meed of praise have won,

The glorious works but just begun,

For Arbor Day, dear Arbor Day. 


\section{SONG OF DEDICATION}

AN ARBOR DAY TREE.

(Air: "Columbia, the Gem of the Ocean.")

The tree we are planting on this day

Is chosen with tenderest care;

May beauty adorn it, hereafter,

And clothe it with usefulness rare.

May green leaves appearing each springtime

Be leaves of a fair book of fame,

And spread to the breezes the story

Extolling the new-given name.

The tree is an emblem of greatness, As, springing from one tiny seed, It mounts ever upward and onward, An emblem of greatness, indeed.

The birds sing its praises to others,

The winds carry swiftly the tale,

The tree is the monarch of the forest,

Of hill, valley, greenwood and dale.

THE PLANTING SONG.

BY DR. S. F. SMITH, AUTHOR OF "A MERICA."

(Air : "America.")

Joy for the sturdy trees

Fanned by each fragrant breeze,

Lovely they stand.

The song birds o'er them thrill,

They shade each tinkling rill,

They crown each swelling hill,

Lowly or grand.

Plant them by stream or way, Plant where the children play,

And toilers rest.

In every verdant vale,

On every sunny swale-

Whether to grow or fail,

God knoweth best.
Select the strong, the fair, Plant them with earnest care No toil is vain.

Plant in a fitter place, Where, like a lovely face, Set in some sweeter grace, Change may prove gain.

God will his blessings send, All things on him depend. His loving care.

Clings to each leaf and flower, Like ivy to its tower.

$\mathrm{His}$ presence and $\mathrm{His}$ power Are everywhere.

\section{ARBOR DAY MARCH.}

BY ELLEN BEAUCHAMP.

(Air: "Marching Through Georgia.")

Celebrate the Arbor Day

With march and song and cheer.

For the season comes to us

But once in every year;

Should we not remember it

And make the mem'ry dear;

Memories sweet for Arbor Day.
Flow'rs are blooming all around, Are blooming on this day;

And the trees with verdure clad, Welcome the month of May,

Making earth a garden fair To hail the Arbor Day, Clothing all nature with gladness.

Chorus:

Hurrah! Hurrah! The Arbor Day is here;

Hurrah! Hurrah! It gladdens every year,

So we plant a young tree on blithsome Arbor Day,

While we are singing for gladness. 
SPRINGTIME.

BY ELLEN BEAUCHAMP.

(Air: "Auld Lang Syne.")

The winter storms have passed away, And springtime now is here

With sunshine smiling all around, And heavens blue and clear.

The gifts of nature brighten earth, And Nature her garden gay;

They give us a cheery greeting bright On this, the Arbor Day.
The birds with gladsome voices sing

Each its melodious lay,

And nusic swells each little throat

On this, the Arbor Day.

The trees put forth their greenest leaves On this, the Arbor Day.

And welcome now the chosen tree

Which we shall plant to-day.

"The Brave Old Oak" is an excellent song for the Arbor Day program.

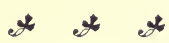

PLANT A TREE.

He who plants a tree,

Plants a hope.

Rootlets up through fibres blindly grope;

Leaves unfold into horizons free.

So man's life must climb

From the clods of time

Unto heavens sublime.

Canst thou prophesy, thou little tree,

What the glories of thy boughs shall be?

He who plants a tree,

Plants a joy ;

Plants a comfort that will never cloy.

Every day a fresh reality.

Beautiful and strong,

To whose shelter throng,

Creatures blithe with song.

If thou couldst but know, thou happy tree,

Of the bliss that shalt inhabit thee.
IIe who plants a tree,

He plants youth;

Vigor won for centuries in sooth;

Iife of time, that hints eternity!

Boughs their strength uprear,

New shoots every year

On old growths appear.

Thou shalt teach the ages, sturdy tree, Youth of soul is immortality.

He who plants a tree,

He plants peace.

Under its green curtains jargons cease,

Leaf and zephyr murmur soothingly,

Shadows soft with sleep

Down tired eyelids creep,

Balm of slumber deep.

Never hast thou dreamed, thou blessed tree,

of the benediction thou shalt be.

He who plants a tree,

He plants love:

Tents of coolness spreading out above

Wayfarers, he may not live to see.

Gifts that grow are best;

Hands that bless are blest;

Plant; life does the rest.

Heaven and earth help him who plants a tree,

And his work its own reward shall be. 


\section{THE TREES AND THE SEASONS}

(For four little girls or two little girls and two little boys; if possible have the first dressed in green, the second in yellow, the third in brown and the last one in white, each carrying a wreath or branch typical of the season mentioned.-I. C.)

First Child-

I love a tree in spring

When the first green leaves come out

And the birds build their nests and carol

Their sweet songs round about.

Second Child-

I love a tree in summer,

Whes in the noontide heat,

The reapers lie in its shadow

On the greensward cool and sweet.

Third Child-

I love a tree in autumn,

When Frost, the painter old,

Has touched with his brush its branches,

And left them all crimson and gold.

Fourth Child-

I love a tree in winter,

Mid snow and ice and cloud,

Waving its long, bare branches,

In the north wind, wailing loud.

All-

Let us plant a tree by the wayside,

Plant it with smiles and with tears,

A shade for some weary wanderer,

A hope for the coming years.

\section{A WONDERFUL TREE}

Did you ever hear of a tree bearing glue, towels, cloth, tinder and bread? There is just such a wonder; it is found on the Pacific Islands, and is called the bread fruit tree.

It is about as tall as a three-story house, and the branches come out straight from the tree like so many arms. They are covered with leaves nearly two feet long and deeply gashed at the edges, while half hidden among them are the fruits, growing like apples on short stems, but larger and having a thick, yellow rind.

This fruit is like bread, and it is in season during eight months of the year, the natives finding a good living in it. They gather it while it is green, and bake it in an oven. Scraping off its outer blackened crust, they come to the loaf, which is very much like nice white bread; but it must be eaten soon after baking, else it grows harsh and loses its pleasant taste. 
As for glue, it oozes from the trunk of the tree and is found useful for many purposes; the leaves make excellent towels for the few natives who care to use them, and from the inner bark of the tree a kind of coarse cloth can be made. Besides this its dried blossoms are used for tinder in lighting fires, and the wood is in great demand for building purposes.

With a few of these wonderful trees in the front yard, housekeeping ought to be an easy matter.

\section{FROM THE FOREST}

About sixty per cent of all our railroad ties are made of white oak; nearly twenty per cent are pine. Since every mile of railway needs about 2,500 ties and there are over 200,000 miles of such roads in our country, it takes millions of acres of timber to supply a single set of ties Such a set has to be replaced about every seven years. Thus it is that the railways rank among the greatest consumers of wood in the country.

Our telegraph and telephone poles are made largely from hemlock and cedar. The price paid for such timber varies from two to ten dollars per pole.

Flour barrels are made largely from elm. Barrels for liquids from a fine grade of white oak; also ash and elm.

Our furniture is made from walnut, ash, oak, maple and other hard woods.

White oak and hickory are used in manufacture of wagon and buggy wheels.

Soft woods, as poplar, aspen, spruce, pine and 'basswood, are used in the manufacture of paper such as is used in newspapers, note books, etc.

Three fourths of our lumber is made from soft woods, such as redwood, white pine, spruce and hemlock. The great pineries of Wisconsin, Minnesota and Michigan supply our white pine, the most useful timber in the north temperate zone, because it is in greatest demand for building purposes.

The bark of the tanbark oak tree is used in the tanning of leather.

Corks are made from the bark of the cork oak, which grows only in the Mediterranean countries and Portugal.

As a national industry, forestry stands second only to agriculture in number of people and amount of capital employed and in value of product. It has been estimated that we have five hundred million acres of growing forest, and that thirty-five cubic feet of wood are produced annually per tree. 


\section{WHAT THE TREES TEACH US}

(An exercise for using fourteen pupils of the lower grade; less than this number may be used by omitting certain verses. If each pupil carries a branch of the tree represented the effect is greatly enhanced.)

First Pupil-

I am taught by the Oak to be rugged and strong

In defense of the right; in defiance of wrong.

Second Pupil-

I have learned from the Maple, that beauty to win

The love of all hearts, must have sweetness within.

Third Pupil-

The Beech, with its branches wide-spreading and low.

Awakes in my heart hospitality's glow.

Fourth Pupil-

The Pine tells of constancy. In its sweet voice

Fifth Pupil-

It whispers of hope till sad mortals rejoice.

The nut bearing trees teach that 'neath manners gruff,

May be found as "sweet kernels" as in their caskets rough.

Sixth Pupil-

The Birch, in its wrappings of silver gray,

Shows that beauty needs not to make gorgeous display.

Seventh Pupil-

The Ash, having fibres tenacious and strong,

Teaches me firm resistance, to battle with wrong.

Eighth Pupil-

The Aspen tells me with its quivering leaves,

To be gentle to every sad creature that grieves.

Ninth Pupil-

The Lombardy Poplars point upward, in praise,

Tenth Pupil-

My voice to kind heaven they teach rne to raise.

The Elm teaches me to be pliant yet true;

Though bowed by rude winds, it still rises anew.

Eleventh Pupil-

I am taught generosity, boundless and free,

By the showers of fruit from the dear Apple tree.

Twelfth Pupil-

The Cherry tree blushing with fruit crimson red,

Tells of God's free abundance that all may be fed.

Thirteenth Pupil-

In the beautiful Linden, so fair to the sight,

This truth I discern: It is inwardly white.

Fourteenth Pupil-

The firm rooted Cedars like sentries of old,

Show that virtues deep-rooted may also be bold.

-Helen O. Hoyt, in the Teachers' World.

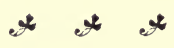

"When the Green Gits Back in the Trees" is an excellent selection in verse by James Whitcomb Riley. It is in dialect and could be recited by a pupil of the grammar grade. 


\section{WHY WE KEEP ARBOR DAY}

(Group the six children upon the stage; seventh child stands at one side; each child wears a crown of leaves.)

Child at the side-

Trees of the fragrant forest, With leaves of green unfurled, Through summer's heat, through winter's cold, What do you do for our world?

First-

Our green leaves catch the raindrops

That fall with soothing sound, Then drop slowly, slowly down,

'Tis better for the ground.

Second-

When rushing dow $n$ the hillside,

A mighty freshet forms,

Our giant trunks and spreading roots

Defend our happy homes.

Third-

From burning heat in summer,

We offer cool retreat,

Protect the land in winter's storm

From cold, and wind, and sleet.
Fourth-

Our falling leaves in autumn,

By breezes turned and tossed,

Will make a deep sponge carpet warm

Which saves the ground from frost.

Fifth-

We give you pulp for paper,

Our fuel gives you heat,

We furnish lumber for your homes, And nuts and fruits to eat.

Sixth-

With strong and graceful outline,

With branches green and bare,

We fill the land all through the year

With beauty everywhere.

All, in concert-

So, listen, from the forest,

Each one a message sends

To children on this Arbor Day,

"We trees are your best friends."

-Primary Education

\section{OUR THREE FAVORITES}

The oak is a strong and stalwart tree,

And it lifts its branches up

And catches the dew right gallantly

In many a dainty cup.

But the world is brighter and better made,

Because of the woodman's stroke,

Descending in the sun or falling in shade,

On the sturdy form of the oak.

The elm is a kindly, good tree,

With its branches bending low;

The heart is glad when its form we see,

As we list to the river's flow.

Ay ! the heart is glad and the pulses bound,

And joy illumines the face

Whenever the goodly elm is found,

Because of its beauty and grace.

The maple is supple, and lithe, and strong,

And claimeth our love anew,

When the days are listless, and quiet and long,

And the world is fair to view.

And later-as the beauties and graces unfold--

A monarch right royally drest,

With streamers aflame and pennons of gold,

It seems of all the best. 


\section{WHICH SHALL IT BE?}

FOR FOUR JOILY BOYS.

First-

If we are all to choose and say What trees we'd like to plant to-day, Seems to me none can be Half so good as a Christmas tree! For surely even a baby knows That's where the nicest candy grows.

Candy on a Christmas tree.

That's what pleases me!

\section{Second-}

Planted out, 'would never bearBut, after all, why should we care? The richest thing is what we bring From sugar maples in the spring; So now I'll set a maple here, For feast and frolic every year. Sugar from a maple tree, That's what pleases me!
Third-

Sweets are good most any day, But as for trees, I'm bound to say, A shag-bark tall is best of all When once the nuts begin to fall; And so a hickory tree I'll set, And piles of fun and nuts I'll get.

Yuts from a hickory tree, That's what pleases me:

Fourth-

I shall plant an apple tree, That's the best of all for me; And each kind to suit my mind, On this one with grafts I'll bind, Ripe or green the whole yearthrough, Pie or dumpling, bake or stew.

Every way I like them best, And I'll treat the rest?

-Youth's Companion.

\section{ESSAYS}

Generally there are to be found in the upper grades pupils especially gifted in writing essays or descriptive articles. Have two or three select topics from the following list, write their articles at home, and when they have been submitted to you select the best to be read as a part of the Arbor Day program:

1. The Big Trees of California.

2. Our State Flower-The Golden Poppy.

3. What We Owe to the Trees.

4. Famous Trees and Little Stories About Them.

5. The Fruit Trees of California.

6. Our Most Useful Trees and Their Products.

7. What the Redwood Told the Oak.

8. The Life of the Oak Tree-Told by Himself.

9. The History of Arbor Day.

10. Trees: The Home of the Birds and Their Nests.

11. The Most Beautiful Tree.

12. How the Tree Breathes and Grows.

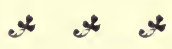

"Woodman, Spare That Tree," by George P. Morris, should be recited on Arbor Day as part of the regular program.

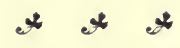

Some afternoon before Arbor Day comes around read the "Talking Oak," by Tennyson, to your pupils. You'll find it worth while. 


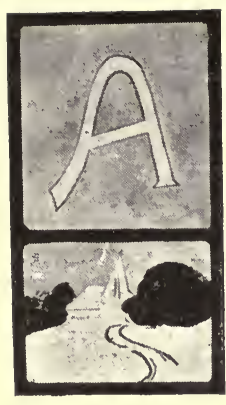

\section{RESFONSIVE READING}

'TEacher: And God said, Let the earth bring forth the fruit-tree yielding fruit after its kind.

Scrool: And the earth brought forth the tree, yielding fruit whose seed was in itself after its kind. And God saw that it was good.

Teacher: And God said, Behold I have given you every tree in the field which is the fruit of a tree yielding seed; to you it shall be for meat.

School: And the Lord planted a garden eastward in Eden, and there put the man whom he had formed. And out of the ground made the Lord (rod to grow every tree that is pleasant to the sight and good for food.

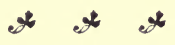

\section{WHEN THE GREEN GITS BACK IN THE TREES}

In the spring when the green gits back in the trees, And the sun comes out and stays,

And your boots pull on with a good tight squeeze, And you think of your barefoot days:

When you ort to work and when you want not,

And you and your wife agrees

It's time to spade up the garden lot-

When the green gits back on the trees,

IVell, work is the least of my ideas

When the green, you know, gits back on the trees

When the whole tail feathers o' winter time

Is all pulled out and gone,

And the sap it thaws and begins to climb, And the sweat it starts out on

A feller's fored a-gittin' down At the old spring on his knees-

I kind o' like, jes, a loaferin' roun'

When the green gits back in the trees-

Jes' a-potterin' roun' as I darn please,

When the green, you know, gits back in the trees.

-James Whitcomb Riley.

\section{$* 2 *$}

\section{SUBJECTS FOR ARBOR DAY CONSIDERATION}

History of Arbor Day. Varieties of trees in California and on our farms. Trees and their relation to birds. Trees and their relation to rainfall. Best trees to plant on the roadside. The most useful trees. How to care for them. Best trees and shrubs for home planting. Schoolhouses: proper interiors and exteriors. School grounds: how to improve them. How to do away with rubbish on the roadside. How to make Arbor Day most useful. 


\section{THREE LITTLE TREES}

(Recitation for a tiny girl. Three other children stand near representing the treeslaughing. whispering, telling secrets, clapping hands, etc., in pretty pantomine to the speaker's words.)

Way out on the orchard in sunshine and breeze, A-laughing and whispering, grew three little trees.

And one was a plum tree, and one was a pear, And one was a rosy-cheeked apple tree rare.

A dear little secret, as sweet as could be, The breeze told one day to the glad apple tree.

She rustled her little green leaves all about, And smiled at the plum, and the secret was out.

The plum told in whispers the pear by the gate, And she told it to me, so you see, it came straight.

The breeze told the apple, the apple the plum, The plum told the pear, "Robin Redbreast has come!" And out in the orchard they danced in the breeze, And clapped their hands softly, these three little trees.

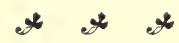

Hail to the Trees:

Patient and generous, mothers of mankind; Arching the hills, the minstrels of the wind, Spring's glorious flowers and Summer's balmy tents. As sharers in man's free and happier sense, The trees bless all, and then brown mantled, stand, The sturdy prophets of a golden land.

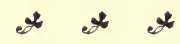

A little of thy steadfastness, Rounded with leafy gracefulness, Old Oak, give me-

That the world's blasts may round me blow, And I yield gently to and fro, While my stout-hearted trunk below And firm set roots unshaken be. -Lowell.

\section{CONCERT EXERCISE FOR LITTLE FOLKS}

\section{FACTS ABOUT ARBOR DAY.}

1. We will remember Arbor Day, for it means tree day.

2. We plant trees on Arbor Day.

3. We little children can not plant large trees, but we can plant seeds.

4. We sing about the flowers and trees on Arbor Day.

5. We speak pieces about the trees, too.

6. We learn wonderful things about the trees.

7 . Trees protect us from the fierce winds.

8. We could have no fires if there were no trees. We get our coal and wood from trees. 
9. Many of our houses are made of trees.

10. Some people have nothing to eat but the fruit from trees.

11. We know we could not live without trees.

12. Trees keep the air pure, and we must have pure air to breathe.

13. After a rainstorm, the millions of leaves and stems and roots hold the tiny drops a long time.

14. This prevents drouths and keeps the earth moist so plants can grow.

15. It rains more in places where trees grow.

16. If it did not rain there would be no springs; there would be no brooks, lakes, and rivers.

17. Our earth would be like a hot, dry desert without trees.

18. We will cut down only the trees we need for use.

19. Trees are among the best friends we have.

20. (All) We will love the beautiful trees.

\section{THREE TREES}

The pine tree grew in the wood,

Tapering, straight, and high;

Stately and proud it stood,

Black green against the sky.

Crowded so close, it sought the blue,

And ever upward it reached and grew.

The oak tree stood in the field,

Beneath it dozed the herds;

It gave to the mower a shield,

It gave a home to the birds.

Sturdy and broad, it guarded the farms,

With its brawny trunk and knotted arms.

The apple tree grew by the wall,

Ugly and crooked and black;

But it knew the gardener's call,

And the children rode on its back.

It scattered its blossoms upon the air,

It covered the ground with fruitage fair.

"Now, hey," said the pine, "for the wood!

Cone live with the forest band.

Our comrades will do you good,

And tall and straight you will stand."

And he swung his boughs to a witching sound, And flung his cones like coins around.

"O ho!" laughed the sturdy oak;

"The life of the field for me.

I weather the lightning stroke;

My branches are broad and free,

Grow straight and slim in the wood if you will,

Give me the sun and the wind-swept hill." 
And the apple tree murmured low:

"I am neither straight nor strong;

Crooked my back doth grow

With bearing my burdens long."

And it dropped its fruit, as it dropped its tear,

And reddened the ground with fragrant cheer.

And the Lord of the Harvest heard,

And he said: "I have use for all;

For the bough that shelters a bird,

For the beam that pillars a hall;

And grow they tall, or grow they ill,

They grow but to wait their master's will."

So a ship of oak was sent,

Far over the ocean blue;

And the pine was the mast that bent,

As over the waves it flew;

And the ruddy fruit of the apple tree

Was borne to a starving isle of the sea.

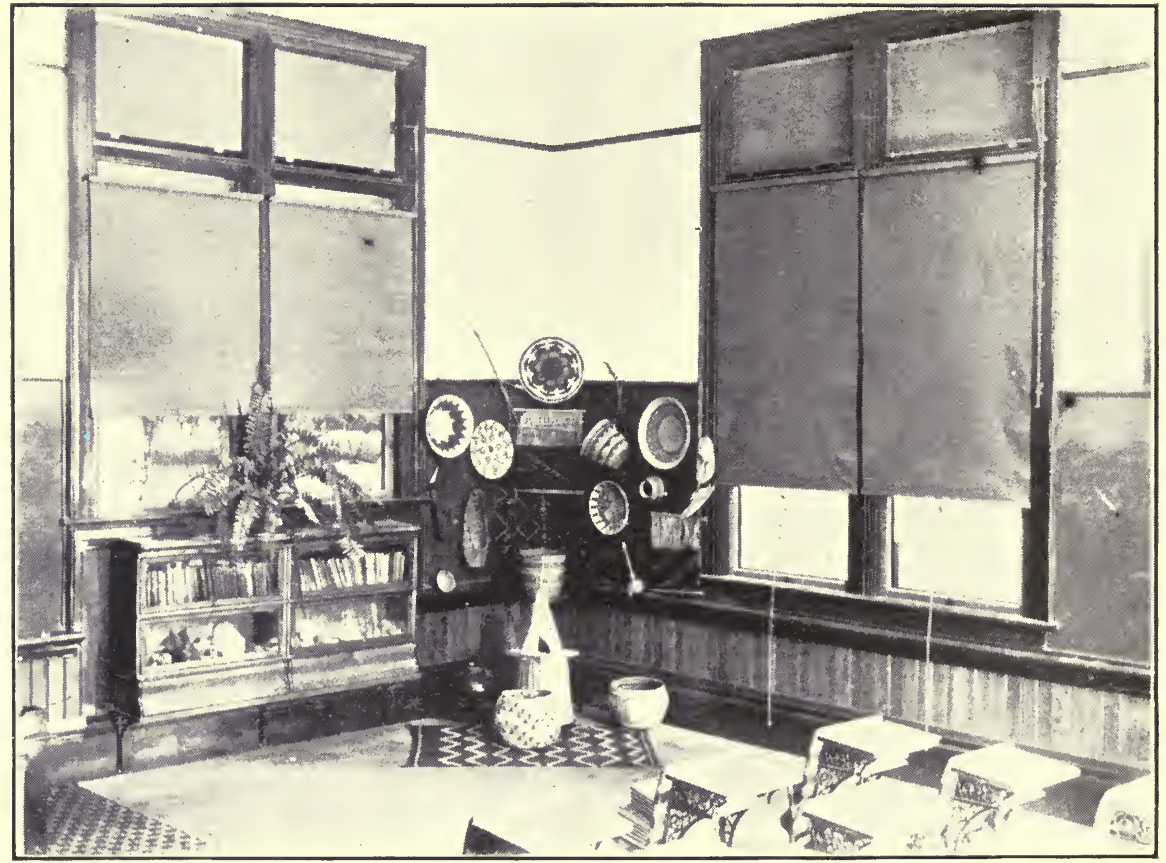

A pretty corner in a schoolroom, showing how a plant may be used to an advantage. The bit of green adds beauty to the room and affords rest for tired little eyes. 


\section{THE LITTLE PLANT}

In my little garden bed Raked so nicely over, First the tiny seeds I sow, Then with soft earth cover.

Shining down, the great round sun Smiles upon it often;

Little raindrops pattering down, Help the seeds to soften.

Then the little plant awakes!

Down the roots go creeping,

Up it lifts its little head

Through the brown mold peeping.

High and higher still it grows

Through the summer hours,

Till some day the happy buds

Open into flowers.

\section{GEMS OF THOUGHT FOR ARBOR DAY}

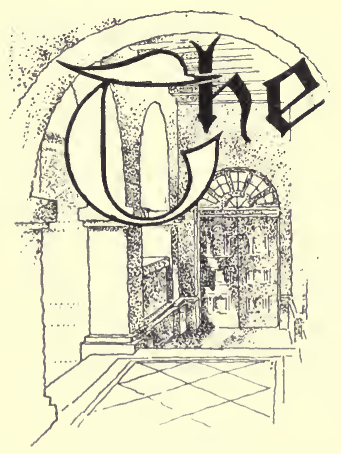

following selected gems are suitable as answers to roll call; may be made part of an essay; may be recited; written or printed on the blackboard with colored chalks; or any use to which a live teacher sees fit to put them.

In freedom's air we plant the tree,

Our land of hope, America;

Beneath the blue sky, freedom's dome,

With in the green earth, freedom's home,

We plant the tree for years to come,

And pray, God bless America.

\section{-Butterworth.}

Dear little tree that we plant to-day,

What will you be when we're old and gray?

"The savings bank of the squirrel and mouse,

For robin and wren an apartment house,

The dressing-room of the butterfly's ball,

The locust's and katydid's concert hall,

The schoolboy's ladder in pleasant June,

The schoolgirl's tent in the July moon,

And my leaves shall whisper them merrily,

A tale of the children who planted ne." 
Our years, our schoolhouse yards, and the resting places of our dead, should not be neglected, but should be adorned with nature's own beautifiers-the trees.-Bates.

.The tall oak, towering to the skies,

The fury of the wind defies,

From age to age, in virtue strong,

Inured to stand and suffer wrong.

What earnest worker, with hand and brain, for the benefit of his fellowmen, could desire a more pleasing recognition of his usefulness than the monument of a tree, ever growing, ever blooming, and ever bearing wholesome fruit?-Irving.

Summer or winter, day or night,

The woods are an ever new delight;

They give us peace, and they make us strong,

Such wonderful balms to them belong;

So, living or dying, l'll take mine ease,

Under the trees, under the trees.

-Stoddard.

I shall speak of the trees as we see them, love them, adore them, in the fields where they are alive, holding their green sunshades over our heads, talking to us with their hundred thousand whispering tongues, looking down on us with that sweet meekness which belongs to huge but limited organism - which one sees most in the patient posture, the outstretched arms and the heavy drooping robes of these vast beings, endowed with life, but not with soul-which outgrow us and outlive us, but stand helpless, poor things-while nature dresses and undresses them.-Holmes.

There isn't a blossom under our feet

But has some teaching short and sweet

That is richly worth the knowing.

When we plant a tree we are doing what we can to make our planet a more wholesome and happier dwelling place for those who come after us, if not for ourselves.- Oliver Wendell Holmes.

Give fools their gold and knaves their power;

Let fortune's bubbles rise and fall;

Who sows a field, or trains a flower,

Or plants a tree, is more than all.

-Whittier.

He who plants a tree,

He plants love;

Tents of coolness spreading out above

Wayfarers, he may not live to see

Gifts that grow are best,

Hands that bless are blest ;

Plant; life does the rest.

Heaven and earth help him who plants a tree,

And his work its own reward shall be. 
The tree planter and teacher united in one shall be declared the best benefactor of modern times-the chief provider for posterity.--Morton.

The man who builds does a work which begins to decay as soon as he is done, but the work of the man who plants trees grows better and hetter, year after year, for generations.

To avert treelessness; to improve the climatic conditions; for the sanitation and embellishment of home environments; for the love of the beautiful and useful combined in the music and majesty of a tree, as fancy and truth unite in an epic poem, Arbor Day was created.

The planting of a tree, the tender care bestowed upon it, the eager watching for new developments in its growth, the tending of a flower bed, the training of a vine, will for many a child prove the "open sesame" into the charmed circle of those forces and factors of the natural world which purify, refine, and ennoble the heart of man.-Mull.

When we plant a tree we are doing what we can to make our planet a more wholesome and happier dwelling place for those who come after us, if not for ourselves. As you drop the seed, as you plant the sapling your left hand hardly knows what your right hand is doing. But Nature knows, and in due time the Power that sees and works in secret will reward you openly.-Holmes.

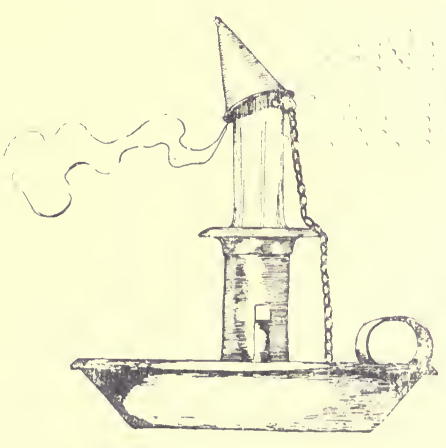






THIS BOOK IS DUE ON THE LAST DATE STAMPED BELOW

AN INITIAL FINE OF 25 CENTS WILL BE ASSESSED FOR FAILURE TO RETURN THIS BOOK ON THE DATE DUE. THE PENALTY WILL INCREASE TO 50 CENTS ON THE FOURTH DAY AND TO \$1.00 ON THE SEVENTH DAY OVERDUE.

\section{MAR 151933}

\section{ำแำ16 1933}


YC 57761

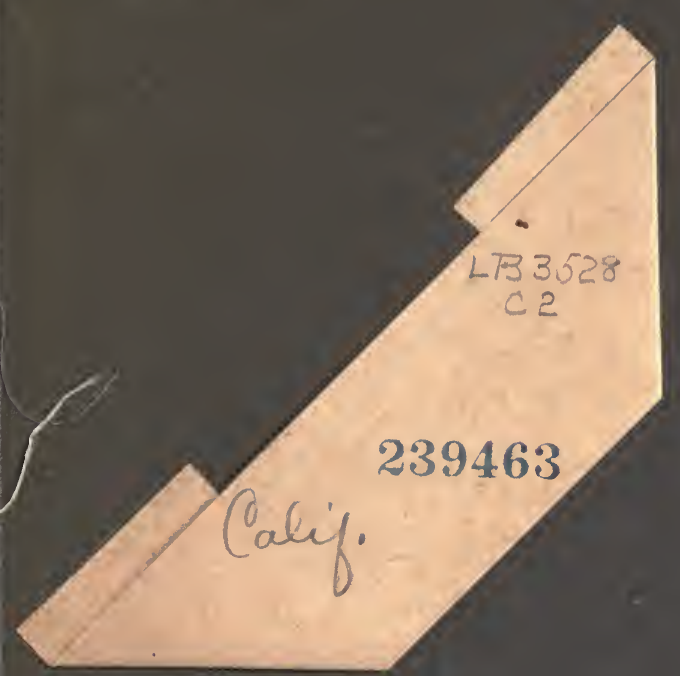


